\title{
The Unofficial Economy in Croatia : Causes, Size and Consequences
}

Bićanić, Ivo; Ott, Katarina

Source / Izvornik: Occasional Paper Series, 1997, 1, 1 - 45

Journal article, Published version

Rad u časopisu, Objavljena verzija rada (izdavačev PDF)

https://doi.org/10.3326/ops.3

Permanent link / Trajna poveznica: https:/urn.nsk.hr/urn:nbn:hr:242:151224

Rights / Prava: Attribution-NonCommercial-NoDerivatives 4.0 International/ImenovanjeNekomercijalno-Bez prerada 4.0 međunarodna

Download date / Datum preuzimanja: 2023-04-26

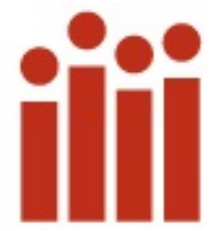

Repository / Repozitorij:

Institute of Public Finance Repository

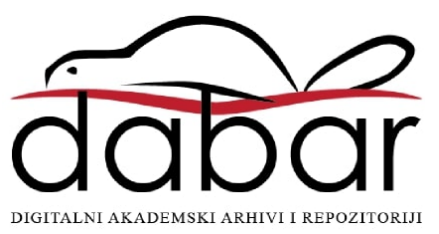




\title{
THE UNOFFICIAL ECONOMY IN CROATIA: CAUSES, SIZE AND CONSEQUENCES
}

Ivo Bićanić \& Katarina Ott

Occasional Paper No. 3

November 1997

\author{
Institute of Public Finance \\ Katančićeva 5, 10000 Zagreb \\ CROATIA \\ tel: +38514591227 \\ fax: +38514819365 \\ ured@ijf.hr \\ (C) Institute of Public Finance 1997
}




\title{
THE UNOFFICIAL ECONOMY IN CROATIA: CAUSES, SIZE AND CONSEQUENCES
}

\author{
Ivo Bićanić \& Katarina Ott
}

This Occasional Paper reports the research results of a project on the unofficial economy in Croatia conducted by the Institute of Public Finance in Zagreb for the Croatian Ministry of Finance. The project team report was finalized in early 1997 and it includes some 15 papers which can be obtained both in Croatian ("Financijska praksa", Vol. 21, No. 1-2, June 1997) and English (http://www.ijf.hr/finpraksa/eng/97/1-2/index.htm). This paper is the summary of the project written by Ivo Bićanić (University of Zagreb) and Katarina Ott (Institute of Public Finance). 


\title{
THE UNOFFICIAL ECONOMY IN CROATIA: CAUSES, SIZE AND CONSEQUENCES
}

\author{
Ivo Bićanić \& Katarina Ott
}

\begin{abstract}
In all economies, there is a part which is not included in the official economy, in other words, economic activities not included in the official statistics. The size of the unofficial economy in the Republic of Croatia was probably at least $25 \%$ of GDP in 1995. Two periods can be clearly distinguished between 1990 and 1996. During the first period up to 1993, all available data indicate that the size of the unofficial economy increased in relation to GDP. The second period began in 1994 and it is not possible to make a final judgement because despite the fact that a majority of indicators suggest a fall, some particularly important indicators point to an increase in the size of the unofficial economy. The calculated size of the unofficial economy in relation to GDP $(25 \%)$ is large and will probably remain so in the foreseeable future because the inherited tradition, the transition with intensified sectoral and institutional restructuring, the large state influence in the economy, especially in privatisation along with the tax pressure, the recovery of growth and new enterprise, only support the unofficial economy. Economic policy aimed at suppressing the unofficial economy must: 1) reduce taxes and customs duties (to the extent permitted by the state budget); 2) selectively reduce regulation; 3 ) reduce the role of the public sector and the presence of the state in the economy while liberalising the economy; 4) better estimate the size of the unofficial economy within the overall economy and in individual sectors.
\end{abstract}




\section{THE UNOFFICIAL ECONOMY IN CROATIA: CAUSES, SIZE AND CONSEQUENCES}

\section{INTRODUCTION}

For the needs of the project a wide definition of the unofficial economy was accepted. Unofficial economic activities were defined as all those economic activities, with the exception of prostitution, drugs and organized crime, not included in official government statistics. As a consequence not all activities included in the unofficial economy are illegal.

Among the various definitions found in the literature this definition was chosen because it is suitable for understanding the unofficial economy in economies in transition. This is best illustrated by two examples. First, economies in transition have undeveloped statistical methods and are themselves being developed so that statistics are often found to be unreliable. Second, the sharp decline in production and wages with the erosion of social entitlements which occurs during the first years of transition has led many social groups into additional economic activities many of which are not illegal.

The Occasional paper is organized as follows. There are three parts to the paper. The first part is made composed of one section which discusses the general causes of the unofficial economy in Croatia. The second part is composed of the next five sections and deals with the aggregate size and share and the sectoral importance of the unofficial economy. Thus the second section attempts to determine the aggregate share of the unofficial economy while the third section analyses the sectoral differences in the size of the unofficial economy. The fourth section discusses the very important relationship of the unofficial economy and the state, this section also includes the role of the unofficial economy in privatization. The fifth section focuses on changes in the size of the unofficial economy during the 1990's. The sixth section brings together the analyses of the previous sections and concludes the analyses regarding the measurement of the size of the unofficial economy. The third section follows in the final two sections which deal with policy aspects of the unofficial economy. Section seven makes policy recommendations. The final, eight section offers some conclusions on the policy aspects. 


\section{CAUSES OF THE UNOFFICIAL ECONOMY}

The papers included in the research project report dealt with various aspects of the unofficial economy. Thus they understandably identified different possible causes for the unofficial economy in Croatia. The causes noted in the papers are numerous, varied and sometimes even contradictory. The most important causes can, however, be listed as follows:

1. The assumption of some authors is that the growth of the unofficial economy in the economy as a whole (measured by the system of national accounts) up to 1993 may have been influenced by the decrease of real incomes, high inflation, the existence of parallel means of payment in domestic transactions, the high tax burden and the war. The decrease of the unofficial economy after 1993 might been influenced by sales, income and profit tax relief (Madžarević and Mikulić, 1997).

2. Regarding the growth of the unofficial economy in industry, agriculture and trade up to 1993, it is assumed that the decisive factors were inadequate and insufficient financial control (the war, establishing of the new state which has yet to develop its own institutions), drop in production and real incomes (when people turn to the informal trade sector), transition reasons (cut in the number of employees in the formal sector accompanying privatisation and restructuring processes) and search for alternative and cheaper supply sources. The decrease of the unofficial economy in 1994 could have been caused by the development of financial control, decrease in taxation rates, restructuring of big retail chains, real income increase, etc. The unexpected renewed growth of the unofficial economy in 1995, in spite of financial control and further growth of real incomes, could be explained by a high rate of personal consumption, cheaper goods from imports compared with goods produced in Croatia, structural changes in consumption and a stronger demand for durable goods (Mikulić and Madžarević, 1997).

3. The unofficial economy in international exchange could be explained by the same reasons and causes which are also found in other countries in transition (slow economic growth, high unemployment rates, high marginal tax rates and high level of public consumption). In Croatia, however, the following factors are especially apparent: inefficiency in the process of privatisation, non-existent industrial policy, problems associated with the economy of scale, shortcomings in the legal system (the adjustment of the legal system to the market economy not yet completed) and lack of robust penalties aimed at preventing illegal activities (Reljac, 1997). 
4. The following causes may account for the role of the unofficial economy in privatisation:

a) the concept of privatisation chosen which has produced unfavourable consequences due to privileged sale (centralisation on the level of state administration of all decisions concerning ownership transformation and privatisation; transfer of a significant part of social-owned capital into state-owned property; choosing important buyers on the basis of political loyalty);

b) concentration of decisions concerning ownership transformation in the hands of a central state agency which is also in charge of the implementation of the process, a fact that further influenced corruption and similar activities;

c) the original legislative decision in which many important practical questions were left undefined, unregulated and unsolved, thus being left to be solved in practice (the Ownership Transformation Law, for example, has undergone six amendments);

d) non-existence of an appropriate information system of privatisation monitoring in the first years of ownership transformation;

e) the impossibility of broader social and political control over state institutions which are under the direct control of the ruling party (Čučković, 1997).

Besides these factors, the unofficial economy during privatisation process was also affected by the following:

a) the war;

b) the inheritance of managerial self-governing socialism (a delay in the privatisation of the banking system made possible the unexpected success of the old management profession in privatisation, but also the consolidation of the elements of the old bank manager structure);

c) the political designs of Croatian capitalism allowed the ruling party to play a role in meriocratic privatisation, political choice of owners and open nepotism, which all resulted in the unofficial economy and unofficial politics living side by side and of politics outside constitutionally based institutional control (Franičević, 1997).

5. The unofficial economy is certainly also influenced by the weaknesses of the Croatian postsocialistic state, such as the non-professionalism and incompetence of public workers and government officials, corruption, favouritism, overloaded administrative, inspection and especially the judicial system, etc. (Franičević, 1997). 
6. Another specific feature is the large number of small firms and companies which are more inclined to operate in the unofficial economy and which mostly belong to the economic branches which themselves have tendencies towards the unofficial economy (such as trade, financial and other services and construction). It is interesting that a large number of informal activities are performed by economic entities which are part of the official economy. The reason for this can be found in the liberal regime and in low costs of registering companies from the period between the Yugoslav Enterprises Act to the Croatian Companies Act of 1996 (Franičević, 1997).

7. Štulhofer (1997) provides a sociologists view of the causes by explaining the process taking place in countries in transition. After the initial exhilaration caused by the fall of communism (and, in the case of Croatia, also by its break with Yugoslavia), a discrepancy develops between subjective expectations (high aspirations) and objective reality. This can be seen in: (a) impoverishment, with the unofficial economy representing a means of survival, social peace and maintaining own standard of living; (b) increased inequality and the gap between the new entrepreneur elite and the rest of the population, with the unofficial economy being a way of becoming rich overnight; (c) unemployment, meaning that without significant economic growth, the pressure of the unemployed leads to spread of the unofficial economy and (d) reducing the level of public services, which, together with discontent with these services (such as health care and pensions) stimulate tax and contribution evasion

8. Transition means institutional changes which also contribute to development of the unofficial economy, such as privatisation, taxation policy and sanctions. In Croatia privatisation best illustrates the area where the 'strategies for side-stepping barriers' are seen best (Čučković, 1997), or, in other words, these areas where a way can be found to become an owner or a stock-holder without sufficient capital of one's own. The main difficulty here is the fact that the unofficial economy in such cases is almost impossible to measure. Some specific problems are: (a) the question of privatisation revision regarded as a political, and not an economic, legal or moral problem; (b) non-transparency and concentration of decision-making power in the hands of state officials, which results in the absence of public control, the appearance of state clientelism and favouring politically determined and often regionally characterised networks of acquaintances. In a word, confidence in state institutions is destroyed and breaking rules and norms is justified. 


\section{THE AGGREGATE SIZE OF THE UNOFFICIAL ECONOMY IN CROATIA}

In applied economic analysis three approaches are commonly used for the indirect measurement of aggregate size of the unofficial economy and its share in GDP. All three of them were applied in this research project: the first, based on differences between differently assessed basic macroeconomic aggregates; the second, that starts from the estimate of employment generated by the unofficial economy; the third, which derives the size of the unofficial economy from money flows.

The first three parts of this section consider the results of each of these methods of estimation, while the fourth part offers an estimate of the total size of the unofficial economy in the Croatian economy as a whole. In analysis of the unofficial economy in Croatia, the first two approaches produced useful results, while the third, although useful for other purposes, is not acceptable without further analytical extension.

\subsection{The Size of the Unofficial Economy Calculated on the Basis of National Accounts}

Calculation of the size of the unofficial economy on the basis of national accounts was described in detail by Madžarević and Mikulić (1997). Their approach seems very simple. Gross domestic product (GDP) has been assessed by two mutually independent methods and the resulting difference between the two estimates is understood as the size of the unofficial economy. GDP was estimated by the income and expenditure method. In the case of the Croatian economy, the expenditure method seems to be constantly and considerably higher than the income method.

In spite of its apparent simplicity, the calculation process here is rather demanding because of the unsatisfactory situation in the official statistics which, for example, has no developed methodology for calculation of basic macroeconomic aggregates and the last available household survey data are from now irrelevant 1990; furthermore, a number of business units are not legally bound to report their relevant data to the appropriate authorities at all, the GDP is still on the level of estimates, etc. This method is more demanding in Croatia than in other 
economies. In face of these difficulties, Madžarević and Mikulić had to resort to a number of assumptions and estimates.

In an attempt to calculate the size of the unofficial economy, calculation of domestic production or supply is the easier part of the job. The official economy is based on annual financial statements which have to be submitted to the Payment Agency by the majority of legal entities. To account for entrepreneurs and private agricultural producers, the statistical service has a well established method of reliable estimate of their activities. The estimate of the registered, or official, production can thus be obtained by adding these two values together.

The main problems arise in assessment of total demand. Each of the components is increased by additional assumptions. The lack in official statistics for figures concerning personal consumption has been adjusted by a production estimate derived from sectoral estimate indices. (This estimate is independent from the earlier mentioned calculation of production based on the Payment Agency data.) This estimate is further adjusted to include the change in commodity stock-piles. Since commodity stock-piles are not divided according to types of products in the original data, their incorporation in the calculation requires additional assumptions. In one case, the assumption was that all commodity stock-piles refer to personal consumption (Versions 1 and 2 calculations). In the other, it was assumed that only 60 per cent of stock-piles refer to personal consumption (Version 3 calculation). Officially registered investments have been increased by the assessed amount of private construction. The size of private construction has been calculated on the basis of well established statistical estimates that private construction represents about 30 per cent of official investments. For unregistered imports and exports two assumptions have been used. The first is based on the official data (Version 1) and in the second these numbers have been adjusted by estimated unregistered imports derived from the registered number of cars and buses crossing Croatian frontier and the estimated import of passengers (Version 2).

Calculating total GDP in the above described manner, Madžarević and Mikulić arrived at three estimates of the share of the unofficial economy in the national economy. The first version is based on official but incomplete data. The second version has been supplemented by the data on import and investment and the third by commodity stock-piles data.

The calculation of the unofficial economy in the GDP shows a wide range of values, varying from 18 per cent to 34 per cent, but most of them are approximately 25 per cent. The same value refers to the unweighted average of all the shares calculated. It should be pointed out here 
that all the three measurement methods show equal changes and trends during the period observed. The calculation results are shown in Table 1.

\subsection{The Size of the Unofficial Economy Calculated on the Basis of Employment in the Unofficial Economy}

Measurement of the unofficial economy through employment is based on the obvious need of all economic activities to use work in production. The size of the unofficial economy can be derived from the assessed quantity of work invested and additional assumptions.

Crnković-Pozaić (1997) measured the size of the unofficial economy through the work invested in economic activities in the unofficial economy using two ways optimal for this kind of measurement. The first is based on population activity rate time series (i.e. the sum of employed and unemployed population - or labour force - in relation to the number of working age population). The second approach is based on the labour force survey.

Deriving the size of the unofficial economy from population activity rates time series is based on the empirically established relation between these rates and on long term growth. (The relation is U-shaped, meaning that the activity rates first drop with population growth and then rise again.) This relation between growth and activity rates makes it possible to calculate the number of assumed active population. The difference in employment which is shown by the assumed and the real employment rate is understood to be work in the unofficial economy.

The calculation made by Crnković-Pozaić is based on a basic presumption: the choice of 1991 as reference year. This choice is justified because it was the year when a steady change in the time trend of activity rates started. The registered employment rate dropped that year, along with a simultaneous drop of registered unemployment and a drop in social product. For the following years, assumed active population was calculated by using the activity rate from 1991. The difference between the number of employed calculated in this manner and the registered employed provides the Estimate of employment in the unofficial economy. The measurement is based on the assumption that there was no unofficial economy in the reference year because there was no work invested in the unofficial economy. In fact, the results obtained thus show changes and not size. 
The other method of calculation was based on the data obtained in a pilot survey on labour force presented in official statistics in 1995, when 1,492 households were surveyed in four Croatian counties. The data collected can be applied to the whole country only as far as the four counties chosen are a reliable and true representative sample for Croatia as a whole. The data cannot be compared with earlier data collected because the size of employment in the unofficial economy was broader due to the fact that the number of people working in the unofficial economy also included those for whom that work only represents additional employment. Also, these data are more extensive because they include many additional characteristics of population employed in the unofficial economy.

The results of Crković-Pozaić measurements show that almost 26 per cent of the total number of employed was employed in the unofficial economy. More detailed data are shown in Table2.

\subsection{The Size of the Unofficial Economy Calculated on the Basis of Monetary Flow}

Monetaristic approach to the calculation of the unofficial economy follows from the assumption that doing business in the unofficial economy also involves monetary transactions. This approach is an attempt to use data on monetary aggregates as a way of tracing business operations in the unofficial economy.

The extent of monetaristic measurement in the unofficial economy was researched by Jankov (1997). In spite of the fact that this kind of measurement was found particularly useful by some of the most famous unofficial economy researchers (including the most famous 'mainstream' economist dealing with the unofficial economy, Vito Tanzi), there is no doubt that this approach does not give satisfactory results in the case of Croatia.

Such a firm conclusion is based on the very nature of the measurement method or on the characteristics of Croatian monetary aggregates. Such measurements are based on contrasting long term trends and short term oscillations. However, no sufficiently long term trends as yet exist in Croatian statistics. Croatia has been monetarily independent only five years, and this period was characterised by a phase of hyper-inflation and by only three years with constant prices, which are again, as far as monetary situation is concerned, still under the strong influence of the earlier hyper-inflation period. 
Obviously, standard monetaristic measures, otherwise extremely useful, are not applicable in such circumstances. If we wish to use this approach to the unofficial economy measurement in Croatia, a different method needs to be developed.

\section{SECTORAL ESTIMATES OF THE UNOFFICIAL ECONOMY IN CROATIA}

Besides estimates of the total size of the unofficial economy in Croatia, a part of the research project also dealt with the size of the unofficial economy in specific economic sectors and in the employment structure.

\subsection{Estimate of the Unofficial Economy in Industry}

The estimate of the unofficial economy in industry offered by Mikulić and Madžarević (1997) is based on the incorporation of two assumptions and one characteristic of official statistics. The first assumption is that the tendency towards working in the unofficial economy in small firms and companies is greater than such tendency in large companies. The second assumption is that the payment of unregistered wages is the main cause which stimulates the unofficial economy. (Small firms register smaller wages and thus avoid paying taxes and contributions). The statistical characteristic mentioned is that the data for small firms are not collected

directly. In the accounting system used by the Payment Agency, the original data are calculated in two different ways. One is to assume that equal wages are paid in all firms and companies and another is to assume that the wages paid in small firms are higher than the wages paid in large companies. Additional value calculated in this way is then used as a basis for estimate of the total size of the unofficial economy in industry.

The results of the calculation performed by Mikulić and Madžarević show that the share of the unofficial economy in industry is about 10 per cent (Table 3 ). 


\subsection{Estimate of the Unofficial Economy in Agriculture}

An estimate of the unofficial economy in agriculture is given by Mikulić and Madžarević (1997). In their approach, however, they measured the unofficial economy in only one part of agricultural production, namely in private agricultural production (agricultural production in peasant households). The low level of development and the traditionally unfavourable attitude of disregarding private agricultural producers have resulted in the very poor and unsatisfactory monitoring of their agricultural production. A great part of their production value thus remains out of the scope of official statistics and falls into the unofficial economy.

Mikulić and Madžarević (1997) provide a better estimate of the value of private agricultural production is given in. They base their calculations on the official estimate of quantities produced and evaluate it by market prices (and not by purchase prices as in official statistics). This is specially important for evaluating the non-market part of peasant household production (i.e. that part which is sold in markets and for own needs). This procedure has resulted in the estimate of the lower and upper level of the unofficial economy in Croatian agriculture.

Calculations show that the unofficial economy in agriculture accounted for approximately 11 percent of total agricultural production (Table 4).

\subsection{Estimate of the Unofficial Economy in Trade}

Mikulić and Madžarević (1997) based their calculation of the unofficial economy in trade on the assumption of an unchanged share of goods going through trade in the total net supply (i.e. domestic production adjusted by the estimated registered and unregistered imports and exports). This unchanged share of goods was estimated for every group of goods (the groups being the same as in the official statistics) and the estimates given in two different versions. The first version assumes that in the initial year (1990), there was no unofficial economy. The second version assumes that the unofficial economy was approximately the same as in the economy as a whole, i.e. 20 per cent.

Based on such assumptions, Mikulić and Madžarević have estimated the share of the unofficial economy in trade shown in Table 5. Both methods of calculation have led to the disclosure of 
an extremely high share of the unofficial economy in trade, with the average share for 1995 of approximately 70 percent.

The very high percentages calculated are supported by two additional sources: the employment analysis and annual financial statements for 1995 and the CEME survey of the same year.

\subsection{Estimate of the Unofficial Economy in Tourism and the Hotel and Catering Industry}

In order to measure the size of the unofficial economy in tourism and the hotel and catering industry, Radnić and Ivandić (1997) increased official statistics on the basis of assumptions about the unofficial economy in every area of tourist offer supply. These preliminary assumptions were based on empirical data and earlier estimates. Radnić and Ivandić then assessed the unofficial economy in tourism and the hotel and catering industry for 1994. First, they calculated physical indicators of the unofficial economy and then converted these into monetary values using the values obtained from the surveys. Ex ante, they estimated the unregistered number of guests (physical turnover) in camp sites and motor campgrounds at 20 per cent, in private accommodation facilities at 30 percent and in registered facilities at 2 per cent. Based on such assumptions, they calculated that 12.6 per cent of nights spent remained unregistered. If this number is added to the assessed unregistered use of weekend cottages and visits by persons temporarily working abroad, up to 80 per cent nights spent remains unregistered. The unofficial economy in the hotel and catering industry is derived from surveys of expenditures by tourists and the local population. Since the registered income was 22 per cent smaller than the estimated income in this sector, Radnić and Ivandić concluded that the unofficial economy in tourism and the hotel and catering industry was 22 per cent.

\subsection{Estimate of the Unofficial Economy in International Trade}

Reljac (1997) has not reached any conclusions about the estimate of the unofficial economy in international exchange, although the analysis carried out in her study indicates that quite a significant unofficial economy exists in this sector. 
Her study describes hidden capital outflow (misinvoicing), significant incongruity between foreign and domestic statistics of Croatian international trade (where differences with certain countries amount to millions of \$US) and changes in balance of services which cannot be explained by normal business operations (but can by hidden capital drain).

Special attention is paid to inadequacy of customs administration (with regard to number of employees and the performance of customs control), to the incompleteness and shortcomings of legal regulations (which allow money laundering and foreign currency accounts), to the undefined status of trading with neighbouring countries (especially with the Republic of Bosnia and Herzegovina) and to the unsatisfactory monitoring of international trade in Croatian official statistics.

\subsection{Estimate of Unemployed Population Structure in the Unofficial Economy}

Using extremely interesting survey results, Crnković-Pozaić (1997) shows the structure of persons employed in the unofficial economy in 1995 by occupation and by status in employment. As mentioned earlier, the survey was conducted in four counties and its application to the country as a whole may be questionable. The results are shown in Tables 7 and 8 . The data clearly indicate that there is a marked tendency for persons in all occupations for working the unofficial economy.

\section{THE STATE AND THE UNOFFICIAL ECONOMY}

In any economy, and especially in economy like that of Croatia, the state plays a special role with regard to the unofficial economy. For example, the state can, through its size, tax burden and efficiency of tax collection and judicial system, stimulate the generation, forms and size of the unofficial economy. At the same time, it also tries to do its best to make the unofficial economy as small as possible and to bring as much of the economy as possible into the official sector and thus also under state control. (The same goes for those parts of the unofficial economy which develop independently from any activity performed by the state). For this reason it is important to know how successfully the state copes with the unofficial economy. 
These questions become specially interesting in the periods of turbulent institutional change and redistribution of wealth and economic power.

In badly organised countries, in countries in transformation phases with an ineffective infrastructure, inadequately trained personnel and insufficient control techniques and sources, or in countries where government officials only take advantage of the possibilities offered by the unofficial economy (through, for example, forms of corruption such as blackmail, bribery or personal access to the unofficial economy by which they compensate for their apparent or seemingly low wages), the activities of state officials are much more often a factor influencing the unofficial economy than is usually thought (Clark, 1988). All of these elements can be found in Croatia, especially in the first years after it gained independence.

Among the vast variety of available aspects of the relation between the state and the unofficial economy of which this project research consists, three are worth paying special attention to. The first, deals with tax evasion, the second, refers to the role of the unofficial economy in the privatisation process, and the third, refers to the attitude of the population toward its dealings with the state. Each of these three aspects is described in one of the following paragraphs.

\subsection{Tax Avoidance and Tax Evasion}

Madžarević (1997) calculates tax evasion for total revenue, for individual items of the state budget incomes and the share of tax evasion in total tax revenues. The unofficial economy in the state expenditures is not calculated.

Total tax evasion was calculated on the basis of two assumptions. The first refers to calculation of the real gross social product, i.e. that which includes the unofficial economy. The second assumption was that the share of tax income in the real and in the official gross social product was the same. Potential tax income can be obtained by applying the registered rates on the estimated gross social product. The difference between the registered and the potential tax income Madžarević ascribes to tax evasion.

Three out of five required indicators are provided by the official statistics. Registered gross social product, registered taxes and tax share are all parts of the official statistics. Real gross social product is an estimate derived by Madžarević and Mikulić (1997). Potential tax is used 
as the central indicator. Its calculation is based on the assumption that the share of potential tax in the real gross social product is equal to the share of registered taxes in registered product. The rest of the calculation is based on the relation of the registered and potential taxes. Madžarević produced calculations for the central and general state and the results are shown in Table 9.

Madžarević also calculates tax evasion for individual items of income (income tax, profit tax, goods and services taxation, excise and custom tariffs). Usage of various techniques makes comparison rather difficult, but research resulted in the calculation of total direct and indirect tax evasions. Table 10 shows average values of the lower and the upper level of these evasions. The evasion calculated makes it possible to calculate its share in total state revenues (Table 11).

\subsection{The Unofficial Economy in Privatisation}

One of the key characteristics of the Croatian economy is transition. Transition is, among other things, characterised by a large-scale redistribution of social wealth. Quick redistribution of such dimensions, together with an uncertain, incomplete and constantly changing institutional framework and a short and weak democratic tradition, all add up to provide fertile ground for the ever increasing role which the unofficial economy attains in the privatisation process. This is the conclusion reached by Čučković (1997). Unfortunately, she also indicates the limitations connected with any serious research on the unofficial economy in privatisation. Insufficient data (especially lacking is hard, neutrally collected and reliable information), too short a time period (the redistribution is still in progress and its final results cannot yet be known) and emotional and political charge make analysis very difficult. This statement is even more true if any solidly based general estimates, which are not based on anecdotal assumptions, are to be obtained. 


\subsection{Attitudes Towards Dealings with the State}

The large size of the unofficial economy and significant tax evasion found in Croatia today influence the attitude of population. This relationship was researched by Štulhofer (1997) who used the following four indicators: tax evasion tolerance, bribe tolerance, opportunism indices and confidence in the legal system.

His results show some interesting regularities. Justification for cheating the state of its taxes, or tolerance of tax evasion, is greater among the educated (people with college education), the richer (people with higher average income per member of the household) and people whose employment gives them greater independence. Approximately 63 per cent of people surveyed in a representative sample considered tax evasion acceptable. Besides the tax evasion tolerance, Štulhofer also asked his examinees to answer about taking bribes: 37 per cent considered that bribe acceptance could be justified.

Štulhofer measured opportunism as a weighted mean value of the attitude towards tax evasion and bribe. Younger examinees show greater tolerance both the towards tax evasion and bribes and, consequently, greater tendency towards opportunism than older examinees.

The findings of Štulhofer's research (1997) are also interesting because they show a high level of opportunism in Croatia (higher than such level in Slovakia and Hungary, higher even then the level of opportunism in Romania). More than two thirds of examinees were convinced that the majority of public officials was involved in corruption. Most sensitive is the attitude that law avoidance seems to be considered smart and not a criminal activity and that tax evasion puts a perpetrator high on the social scale instead bringing him down. This seems to indicate that not even actual shameful exposure of tax avoiders would produce much result. Perhaps some results might be achieved by appropriate exposure of the really biggest offenders from the very top political circles. It might indeed be the only way of regaining confidence in institutions and their (politically) impartial control. It would also help to outline more precisely the lines of criminal activities in everyday's perception. Discovery, exposure and appropriate punishment, on the other hand, must not be politically motivated because this would only be perceived as political cleansing in the eyes of the public and would not change the current attitude towards criminal behaviour. Indeed, it might only contribute to an increase of public apathy. 
In spite of political rhetoric in which transitional difficulties are primarily attributed to inherited socio-cultural habits, the collectivist inheritance of the socialist planning system is not the most important cause of today's relatively widespread opportunism and distrust in Croatia. It would most probably be more correct to consider opportunism and distrust in Croatia as a reflection of increased uncertainty (due to the introduction of market competition), a consequence of deep disappointment because of unfulfilled expectations after the breakdown of the planning system and an awareness of political patronage of privatisation and uneasiness resulting from all that.

Awareness of a just legal system, satisfaction with the way high government officials perform their job (directed towards achieving of the general good and not towards their own prosperity) and perception of the extent of corruption in state institutions have proved to be very significant factors. It is also very significant that the data show opportunism and distrust to be more frequent in larger, urban and socially and culturally more developed surroundings with easier access to information and a higher average level of information, etc. The fact that opportunism and distrust in institutions are more pronounced in young than in older examinees is another cause for alarm because it opens the possibility of "natural" reproduction of the unofficial economy and seems to indicate its (possible) long term durability.

The results of a survey of Croatian judicial statistics are alarming. The expenses linked to breaking rules that regulate economic activities are extremely low. The total number of persons legally persecuted is negligibly small and the number of those actually convicted is even smaller. The perpetrators are exposed to very low risk, since the courts of law are overloaded, employees too busy and court decisions take years to become effective. The direct result of this situation is the generally low number of charges actually pursued (Skorupan, 1997).

\section{CHANGES OF THE UNOFFICIAL ECONOMY IN CROATIA IN THE 1990'S}

The best available data about the unofficial economy in Croatia are shown in Tables 1-11. They were calculated according to the procedures described in the sections 3 and 4 of this paper. Although they only represent the first attempts of their kind in the Republic of Croatia,

some characteristics indicate that the reliability of the data can be accepted. The first and very important characteristic is that the data are not in contradiction with the expectations of the 
profession. Another characteristic is that not one of the values calculated stand out from the general picture. On the contrary, for this kind of calculation, numerical results are surprisingly congruent. The third characteristic is that, in spite of all the reservations unavoidable in performing international comparisons, the estimates of the unofficial economy in Croatia tally with the expected rank in the international scale.

\subsection{Estimates and Expectations}

As far as the size and share of the unofficial economy in the Croatian national economy is concerned, a developed unofficial economy was to be expected. The same is true for the size and share of the unofficial economy in the national economy as a whole, for the size and share of the unofficial economy in particular economic branches and, finally, for the changes occurring during the 1990's.

Both general and specific characteristics of the Croatian economy indicate that the unofficial economy in Croatia is large. General characteristics refer to the level of development and economic structure achieved, the influence of the memory of three hyper-inflation periods and only three years of exchange rate and price stability, transition with its sectoral and institutional restructuring and transition crises. Specific aspects are inherited business customs and the size of the unofficial economy, war and the international embargo on weapons, humanitarian aid, an unstable institutional framework, inefficient administration connected with the low risk of working in the unofficial economy, share of the state in the economy, tax burden, etc.

For the 1990-1995 period, the estimate of the share of the unofficial economy in Croatian gross social product varied between 17 per cent and 33 per cent. (Bearing in mind the turbulent events of the period, such a wide range need cause surprise.) These are all high values. Two independent estimates are available for the last year of the period (1995). Calculation by national accounts roughly showed the average share of the unofficial economy in the gross social product of 26 per cent, or an unweighted mean value of average share calculated by more fine-tuned estimates of 23.5 per cent. The labour force survey carried out on a limited area showed a total labour force of 23 per cent invested in unofficial economic activities. (If we assume that the productivity in the official and unofficial economy is the same, the share of the unofficial economy was 25 per cent.) Bearing in mind the topic of our discussion, all these 
estimates are surprisingly similar. Generally accepted inaccuracy accepted in calculations like these allows us to round the figures obtained and an assumption that the share of the unofficial economy in the gross social product of 25 per cent in Croatia in 1995 seems to be quite acceptable.

Sectoral shares of the unofficial economy also support these expectations. The unofficial economy in production sectors should be lower than in service activities. The reason can be found in the fact that transition through market liberalisation in the early phases particularly stimulates the development of all forms of trade. (It is not unusual that in the first transition phase the distribution system was established.) In the production sectors, on the other hand, the very mixed inheritance and special conditions would not have operated to the advantage of any one sector. For example, inherited business customs will more strongly influence the unofficial economy in industry, while level of development will influence agriculture while war and transition which induce tolerance towards any kind of business customs, have no particular sectoral influence.

The data calculated confirm such expectations. The calculated share of the unofficial economy in agriculture for 1994 was 11 per cent, in industry approximately 8 percent, in tourism and the hotel and catering industry 22 per cent and in trade as high as 68 per cent.

Although, with the exception of trade, sectoral shares are smaller than the aggregate share, sectoral estimates are also in line with the aggregate share of the unofficial economy. The reason for this lies in the fact that two important sectors - construction and crafts and trades have not been included in the research, due to the lack and unreliability of relevant data. It is probable that a large share of the unofficial economy is covered exactly by those activities.

As far as temporal changes are concerned, the expectations were clear. Two clearly distinguishable periods were to be expected. The first is characterised by increase in the share of the unofficial economy due to the war, the establishment of the new state, the first years of transition and hyper-inflation. This period was expected to last until the end of 1993. With higher institutional security and exchange rate and price stability, the share of the unofficial economy was then expected to start decreasing or remain unchanged. This second period should begin from 1994.

Almost all the data show exactly the expected changes during the 1990-1996 period. Especially important is the fact that both methods of total share measurement give very similar changes in 
the time period concerned. Calculation of labour changes in the unofficial economy and the share of the unofficial economy in the gross social product show the same trends in all versions and, even more, trends which could have been expected. In other words, the data confirm first an increase in the share of the unofficial economy, which lasted up to 1994, and then a decrease. This trend, however, cannot be ascribed to better efficiency on the part of the tax authorities without further research. The data show that share of registered taxes in potential taxes remained unchanged during this period.

The only exception from the rising trend was a drop in the increase of the unofficial economy in industry and trade recorded between 1994 and 1995. If such a change should continue, it might indicate some very important and interesting, although unexpected changes.

\subsection{Congruity of Numerical Results}

The unofficial economy is, of course, very hard to measure. That is the reason why there are so many estimates based on various assumptions and resulting in various conclusions. Reliability is naturally greater if the estimates result in similar values. The results of unofficial economy measurements in Croatia do just that. Not one value measured shows any significant deviations. This means that differences and changes can be explained by economic factors and not by the quality of measurements.

\subsection{The Share of the Unofficial Economy in Croatia and International Comparisons}

If the measurement of the unofficial economy is hard to perform in one country, the problems facing us in an attempt to conduct international comparison are even greater. In spite of all restrictions connected with such comparisons, the unofficial economy of 25 per cent measured in Croatia in 1995 places Croatia among countries with a high unofficial economy. This is indicated by Bejaković (1997). However, only additional measurement could determine this more specifically and its importance is more of an academic than of a practical nature, i.e. it is not very important for efficient economic policy-making and implementation. 


\subsection{Expected Changes of the Share of the Unofficial Economy in the Croatian Economy}

The research conducted within this Project indicate that a decrease in the unofficial economy is not likely in near future. Franičević (1997) and Štulhofer (1997), Madžarević (1997) and Kesner-Škreb (1997) show that the long term factors underpinning the unofficial economy will most probably remain unchanged. Transition, institutional instability, personal economic uncertainty, sectoral restructuring, quasi-rents and high involvement by the state will remain for some time yet to come. People's attitude population towards the unofficial economy is very likely to further increase in tolerance towards the unofficial economy and, in so doing provide fertile soil for its continuation and even increase. Some of the important factors, such as the war, embargo and exchange rate and price instability have lost their former strength and their influence is nowadays weaker. At the same time, however, new factors have appeared, connected with entrepreneurship and increased and accelerated growth in the neighbouring economic systems with which Croatia has soft borders. Of course, dramatic changes in economic policy could change the share of Croatia's unofficial economy.

While all above seem to indicate that the unofficial economy will continue to remain an important, influential and large part of the Croatian economy, further research is needed to enable reaching any valid, sure and unambiguous conclusions.

\section{CONCLUSIONS CONCERNING MEASUREMENT AND SIZE OF THE UNDERGROUND ECONOMY IN CROATIA}

The research and studies which make up this Project calculate that the share of the unofficial economy in the gross social product in 1995 was most probably at least 25 per cent. The sectoral data show no deviations from the share calculated and varied in 1994 between 8 per cent in industry and 68 per cent in trade. During the 1990-1996 time period, two sub-periods can be clearly distinguished. All the available data indicate that the share of the unofficial economy in the gross social product increased during the first sub-period, which lasted from 1990 to the end of 1993. During the second sub-period, which began in 1994, it seems that the share of the unofficial economy in the gross social product either decreased or remained 
unchanged. However, no unambiguous conclusion can be reached for this period because, in spite of the fact that most of the indicators seemed to have decreased during the period, two important indicators (the share of the unofficial economy in industry and trade) first dropped and then started rising again. Furthermore, during the same period, the data calculated do not show any increased efficiency on the part of the tax administration in tax collection, which poses a question of whether or not the changes can really be explained by greater success in tax collection.

The share of 25 per cent of the unofficial economy in the gross social product is large. Other data, such as the share by economic branches, tax evasion on all levels and the employment of all population categories in the unofficial economy, also indicate that the unofficial economy in Croatia is large. The studies included in this Project and the size of the unofficial economy measured before 1990 all seem to indicate that the unofficial economy is going to remain large also in the following period. Without dramatic changes in economic policy, it will not be possible to reduce the unofficial economy. Most of the factors which influence and stimulate the unofficial economy continue to operate and it is possible, if not probable, that with economic growth new ones may emerge.

There are two answers to questions regarding the unofficial economy which are crucial for economic policy. First, is the unofficial policy large enough to change or influence the efficiency of economic policy? Second, is it large enough to generate economic changes which could influence the economy as a whole? Measurement alone cannot provide answers to those questions, but additional research is needed. The calculated size of the unofficial economy, however, certainly seem to indicate that the answer to both questions is most probably positive.

\section{SOME SUGGESTIONS FOR ECONOMIC POLICY MEASURES REGARDING THE UNOFFICIAL ECONOMY IN CROATIA}

The unofficial economy is not an issue which can be considered on its own. It is difficult to define and, consequently, to speak about in precise terms. Experts engaged in research on the unofficial economy often have to conclude their research without any useful or usable results. It is imperative, therefore, always to be clear on the aim and purpose we wish to achieve, to 
clearly define the problem and then to proceed to develop the research, collect data and, based on them, reach conclusions and propose measures.

The state will have to keep solving the problems of the unofficial economy for a long time yet to come. Special accent will have to be put on: (a) discovering and including economic wealth and changes generated by those actively engaged in the unofficial economy and (b) defining and characterising such activities as criminal and not legitimate. As the state administration attempts to increase its control and draw funds from an increasingly broader range of activities (private, public, legal, quasi-legal, tolerable and criminal), more attention will have to be paid to the problems mentioned (Clark, 1988).

Two questions must be answered first: 1) with which visible elements is the unofficial economy most associated? and 2) who is really interested in defining the unofficial economy? If the problem is defined as:

a) Tax evasion - the Ministry of Finance (or Tax Administration) is most interested and the data on tax evasion, possibilities on improving the taxation system and tax administration should be collected and particular measures should be proposed.

b) Unemployment - the Ministry of Labour and Social Welfare is interested in order to examine possibilities of reducing unemployment benefits and the Ministry of the Economy and the Government are interested in order to stimulate economic growth. Data on the employed and unemployed population should be collected, measures for increasing employment and control of unemployment benefits determined, etc.

c) Economic growth rate - the Government is interested, and it calls for organisation of state statistics to monitor and measure growth and propose ways to stimulate it on the basis of relevant data, etc.

d) Black marketeering - the Ministry of Finance and the Ministry of the Economy are interested and it would be necessary to determine the data on prices of goods and services in Croatia and neighbouring countries, to find out where the discrepancies come from and to eliminate negative elements discovered (such as, for example, taxes, customs duties, inefficiency, rebates), etc.

e) Unauthorised foreign exchange trade - The National Bank of Croatia is interested and the foreign exchange rate should be re-examined. 
In a word, one-aspect only research is not enough to prevent or eliminate the unofficial economy. It cannot provide usable results immediately. Several continuous lines of research are needed, intended for various users and with various purposes, which would use standardised data and overlap in many segments.

Individual studies of other colleagues researching the unofficial economy in Croatia describe in detail the problems of particular forms in which the unofficial economy appears and measures needed for their prevention. Some of them will be mentioned here:

1) Economic policy measures seeking to reduce the unofficial economy should place primary interest on the institutional sphere. In order to better understand the unofficial economy in Croatia, it is essential to understand the relation of the state towards the economy and toward society as a whole. It will not suffice to examine only the motives of private persons (entrepreneurs, employers, workers, consumers, etc.), but also the institutions of the economy and society, i.e. the state as a whole, needs to be examined, or the problem and nature of political sources and the motives and behaviour of politicians and administrators. The border line between the official and the unofficial economy in Croatia is not a problem only because the activities of the official and unofficial economy are closely connected and because the very development of privatisation and market transformation influences the demand for (de)regulation, but also, because on top of all this, the state itself shows a tendency to operate in the grey zone (of politics, laws and the economy) (Franičević, 1997).

2) The state must see that the following goals are realised: a) high professional level of state services; b) complete independence and better organisation and equipping of the judicial system and the exclusive accountability to Parliament of highly professional control and inspection services (independent of the government); c) transparency of rules and regulations and of all procedures where the possibility of rent seeking is a stimulation to the unofficial economy; d) possibility of truly democratic and public control by citizens and their representatives over all state institutions; e) rational state expenses in spending public revenue, but also reduction of over extensive public expenditure (the share of public expenditure in the GDP); f) high quality service from the public sector; g) decisive break with paternalistic capitalism; h) equal conditions for small firms and companies in the capital market so they do not have to look for capital in the grey market (Franičević, 1997).

3) When it comes to reducing the unofficial economy in a particular area, such as foreign trade, the following elements are essential: improvement in the customs services and implementation 
of techniques for improving trade statistics, cost analysis and, consequently, analysis of the price of goods and services, followed by prevention of misinvoicing, etc. It is also essential to undertake the necessary changes in the legal system (eliminate some of the more important shortcomings in laws and introduce stricter sanctions for illegal economic activities in international exchange), to improve official statistics and the efficiency and co-operation between the Customs Office, the Foreign Exchange Inspectorate and the National Bank of Croatia, as well as to constantly monitor trends in international exchange and the most recent systems for their monitoring (Reljac, 1997).

4) Research on tax evasion indicates that the unofficial economy could be reduced by introduction of value added tax (return of prepaid tax introduces better compliance) and the reform of pension system (in the sense that a pension would depend on the amount insurees were willing to pay). If the decrease of tax evasion in 1994 was really influenced by the improvement in tax administration, financial inspection and customs duty administration, their further improvement might be expected to continue exercising a positive effects. Of course, too great a role of the state might negatively influence unofficial economy reduction. When making decisions about measures, it is more important to prevent the causes of the unofficial economy than its negative consequences (penalties, introduction of new taxes, etc.) From the liberal point of view, the unofficial economy will decrease if economic growth, stabilisation, privatisation and restructuring are realised and if the role of the state in the economy is reduced, if taxes are lowered and if the rights the unemployed enjoy are diminished (Madžarević, 1997).

5) Measures should be taken to prevent the part played by the unofficial economy in privatisation by: a) the government, by relieving of duty officials responsible for such conduct (in Hungary, for example, when a high official in the Privatisation Agency took a bribe, the government changed the whole Administrative Council of the Agency as well the responsible Minister of Trade and Industry); b) the police, by efficient investigations when a criminal act is suspected; c) the judiciary, by quick and efficient decisions concerning the charges. Measures to control the unofficial economy in privatisation include: a) clearer and more precise laws which would prevent the state administration from making arbitrary decisions as they please and provide discretionary interpretations of the laws; b) political strength of state authorities to publicly condemn negative actions and an efficient judicial system; c) acceleration and completion of privatisation as soon as possible, which would prevent harmful long term 
consequences or risks of corruption, fraud, bribes, etc.; d) more detailed research on the unofficial economy in privatisation, which would first of all have to have open access to the data in appropriate state institutions (various ministries, funds and agencies). This is particularly important because privatisation of public companies has yet to be effected and in value they far surpass the value of capital which has already been privatised (Čučković, 1997).

\section{CONCLUSIONS CONCERNING THE ECONOMIC POLICY MEASURES TOWARDS THE UNDERGROUND ECONOMY}

Research on the unofficial economy both abroad and in Croatia indicates that we should be extremely sceptical about the prevailing opinion according to which high economic growth, economic liberalisation and reduction of state involvement in the economy will automatically reduce the unofficial economy. To a certain extent it really is true, but taken alone is neither enough, nor explanatory.

The effects of the unofficial economy are contradictory. Any conclusions should, therefore, be reached with utmost care, and with special attention paid to the fact that the unofficial economy might become a permanent feature of the Croatian economy and society. We should not be deceived by opinions that the unofficial economy is only a legacy from the past or the consequence of as yet incomplete transformation into the market economy.

Accelerated economic growth may be one of the ways to reduce the unofficial economy, but it may also be a new stimulant to unofficial economic growth due to new opportunities for the fast development of entrepreneurship resulting from such growth. However, if the real source of the unofficial economy is the state itself and the way it intervenes in the economy, the unofficial economy will certainly survive. But, as Franičević (1997) points out, the legitimacy of capitalism can be established only by reliable and firm sanctions when the rules of the game are broken, and by increasing the reputation of law-makers and legal authority in general. This does not mean that political campaigns should be conducted which would produce no results, except to further decrease the reliability of the government and the introduction of arbitrary political decisions instead of the legal and proper functioning of the state bodies. A privatised market economy requires institutionalisation and penalties when the rules are broken. This will ultimately be the goal of the new entrepreneurs who have succeeded thanks to the unofficial 
economy. They will want to continue developing, protect themselves from new competition and improve their own standing. People who used to be 'financial engineers' yesterday are the owners of saving-banks today and will want to be bank owners tomorrow, all of which will require regulation, reputation, etc.

All countries have an unofficial economy, from the very richest to the extremely poor ones, the reasons for it may be similar or they may be different. Participants in the unofficial economy may be trinket sellers in the streets of Calcutta, members of the European aristocracy in luxurious villas in Monaco or Harvard graduate lawyers in a simple log house somewhere in the deep forests of Vermont. They are variously stimulated by hunger and the need to provide for their many children, by evasion of high margin tax rates or simply by the resentment they feel for the state and the material goods of modern civilisation.

Obviously, the unofficial economy is very widespread. In Croatia, considering the short term, it will be influenced by poverty, falling behind in development, etc. In the long term, it will be influenced by a post-materialistic trend present even in the most developed countries. In any case, it would be advisable to prepare for living with the unofficial economy, try to understand it as much as possible, measure it and manage it.

Nowadays, Croatia is somewhere in between. The war resulted in a large number of unemployed, impoverished and displaced persons, who were forced to black market food from neighbouring countries and to engage in working on the black market without paying taxes and contributions, in order to survive. While at the other end of the scale were the new entrepreneurs who employed people without registering them with the appropriate authorities, avoided paying taxes and contributions and regular registration in general. The children of this new, rich class have now begun to take over and will perhaps come to understand the benefits of post-materialism and hopefully break with the system of values their parents have.

All these represent potential participants in the unofficial economy and Croatia is now at a cross-road. Establishing a new state with new institutions after forcibly breaking with the former system of values, Croatia has two choices. There is a group of countries where the unofficial economy is only a side-effect of the official economy. The state monitors it, knows it, tolerates it and takes measure to control that part which is against its interests. There is another group of countries where the unofficial is the prevalent economy, along with a Mafia and all the corruption, lawlessness, anarchy and hopelessness which are bound to follow. It is up to the state, to the measures it will take within the bounds of its economic policy and within 
its constitutional, judicial and political norms and regulations, to decide which road it is going to take.

\section{TABLES}

Table 1. Estimated Share of the Unofficial Economy Based on the Estimate of Aggregate Supply and Demand

(\% registered gross social product)

\begin{tabular}{||l|r|r|r|r|r|r|r||}
\hline & \multicolumn{1}{|c|}{1990} & \multicolumn{1}{c|}{1991} & \multicolumn{1}{c|}{1992} & \multicolumn{1}{c|}{1993} & \multicolumn{1}{c|}{1994} & \multicolumn{1}{c|}{1995} & Average \\
\hline 1 & 25.89 & 28.03 & 29.30 & 38.17 & 37.43 & 32.61 & 25.67 \\
\hline 2 & 17.81 & 19.39 & 21.72 & 29.71 & 28.56 & 22.72 & 23.32 \\
\hline 3 & 22.84 & 22.96 & 24.71 & 33.72 & 32.80 & 24.24 & 26.88 \\
\hline Average & 22.18 & 24.82 & 25.24 & 33.87 & 32.93 & 26.52 & 27.59 \\
\hline
\end{tabular}

1. Calculation based only on official data.

2. Official data on imports and exports and investments in the calculation are adjusted by additional assumptions.

3. Official data on imports and exports, investments and commodity stock-piles in the calculation are adjusted by additional assumptions.

\section{Table 2. Employment in the Unofficial Economy}

(\% total employment)

\begin{tabular}{||l|r|r|r|r|r|r||}
\hline \hline 1 & \multicolumn{1}{|c|}{1991} & 1992 & 1993 & 1994 & 1995 & \multicolumn{1}{c||}{1996} \\
\hline 1 & 0.0 & 6.42 & 16.79 & 19.03 & 17.05 & 15.53 \\
\hline 2 & & & & & 25.79 & \\
\hline
\end{tabular}

1. Calculation based on the relation between the assumed and registered population activity rates

2. The Survey on Employment results. 
Table 3. The Share of the Unofficial Economy in Industry ( $\%$ of total added value of industry)

\begin{tabular}{||l|r|r||}
\hline & \multicolumn{1}{|c||}{1994} & \multicolumn{1}{|c|}{1995} \\
\hline Equal wages for all & 5.5 & 7.7 \\
\hline Slightly higher wages & 10.7 & 14.0 \\
\hline Average & 8.1 & 10.9 \\
\hline
\end{tabular}

Table 4. The Unofficial Economy in Agriculture in Croatia (\% registered production)

\begin{tabular}{||l|r|r|r|r|r||}
\hline & \multicolumn{1}{|c|}{1990} & \multicolumn{1}{|c|}{1991} & \multicolumn{1}{|c||}{1992} & 1993 & 1994 \\
\hline Lower level & 6.5 & 7.0 & 7.6 & 6.6 & 6.8 \\
\hline Upper level & 15.3 & 16.8 & 19.0 & 15.6 & 16.2 \\
\hline Average & 10.9 & 11.9 & 13.3 & 11.1 & 11.5 \\
\hline
\end{tabular}

Table 5. Estimate of the Share of the Unofficial Economy in Trade $(\%$ share in total trade turnover)

\begin{tabular}{||l|r|r|r|r|r|r||}
\hline \hline 1 & \multicolumn{1}{|c|}{1990} & \multicolumn{1}{c|}{1991} & \multicolumn{1}{c|}{1992} & \multicolumn{1}{c|}{1993} & \multicolumn{1}{c|}{1994} & \multicolumn{1}{c||}{1995} \\
\hline 2 & 0.0 & 22.1 & 42.0 & 69.6 & 44.2 & 53.2 \\
\hline Average & 10.0 & 34.6 & 56.2 & 86.1 & 58.7 & 68.6 \\
\hline \hline
\end{tabular}

1. Calculation derived on the basis of the assumption that there were no unofficial economy in 1990.

2. Calculation derived on the basis of the assumption that the unofficial economy in 1990 was the same as in other economic activities, i.e. 20 per cent. 
Table 6. Estimated Size of the Unofficial Economy in Tourismand the Hotel and Catering Industry (\% total estimated turnover)

\begin{tabular}{||l|c|}
\hline & 1994 \\
\hline $\begin{array}{l}\text { Unofficial economy in tourism and the hotel } \\
\text { and catering industry }\end{array}$ & 22 \\
\hline
\end{tabular}

Table 7. Persons Employed in the Unofficial Economy in 1995 by Occupation

\begin{tabular}{||l|r|r||}
\hline \hline Employed persons - total & 100 & \\
\hline Persons employed in the unofficial economy & 25.79 & 100 \\
\hline Persons employed in the unofficial economy & 6.23 & 24.2 \\
\hline Persons employed in additional occupations & 10.23 & 39.7 \\
\hline Helping members & 2.30 & 8.9 \\
\hline Other independent professions & 7.02 & 27.2 \\
\hline Housewives, students, unemployed and retired persons & & \\
\hline
\end{tabular}

Table 8. Status in Employment of Persons Working in the Unofficial Economy (\% total persons employed in the unofficial economy)

\begin{tabular}{||l|r||}
\hline \hline Companyowners, entrepreneurs, independent professions & Total \\
\hline Persons employed in the state or local sector & 17.33 \\
\hline Persons employed in private sector & 11.14 \\
\hline Helping members & 40.76 \\
\hline Own-account workers & 9.24 \\
\hline
\end{tabular}


Table 9. Share of Tax Evasion in Central and General Government

(\% estimated GSP)

\begin{tabular}{||l|r|r|r|r|r|r||}
\hline \hline 1 & 1991 & 1992 & \multicolumn{1}{c|}{1993} & \multicolumn{1}{c|}{1994} & \multicolumn{1}{c|}{1995} & \multicolumn{1}{c|}{$1996^{*}$} \\
\hline 1 & 6.23 & 6.52 & 8.31 & 9.40 & 9.26 & 9.06 \\
\hline 2 & 14.86 & 11.48 & 14.37 & 15.87 & 15.12 & 15.06 \\
\hline
\end{tabular}

*GSP according to the estimate by the Ministry of Finance

1. Central government

2. General government

Table 10. Average Share of the Estimated Upper and Lower Evasion of Direct and Indirect Taxes

(\% general the state in the estimated GSP)

\begin{tabular}{||r|r|r|r||}
\hline & 1994 & 1995 & $1996^{*}$ \\
\hline 1 & 3.59 & 4.48 & 4.68 \\
\hline 2 & 3.52 & 5.21 & 5.05 \\
\hline
\end{tabular}

*GSP according to the estimate by the Ministry of Finance

1. Indirect tax evasion (income and profit tax)

2. Direct tax evasion (turnover tax, excise, customs tariffs)

Table 11. Share of Tax Evasion in Total Tax Revenue of General Government (\% upper and lower level in GSP)

\begin{tabular}{||c|c|c|c||}
\hline & 1994 & 1995 & $1996 .^{*}$ \\
\hline 1 & 22.08 & 22.68 & 22.68 \\
\hline
\end{tabular}

*GSP according to the estimate by the Ministry of Finance

1. Lower and upper level average 


\section{SUMMARY}

In all economies, there is a part which is not included in the official economy, in other words, economic activities not included in the official statistics. The size and the changes of the unofficial economy are important because it could be the source of independent economic changes and influence the direction and strength of economic policy.

The size of the unofficial economy in the Republic of Croatia in was probably at least $25 \%$ of GDP in 1995. Data on separate sectors correspond to those of the official economy and in 1994 ranged from $8 \%$ in manufacturing industry up to $68 \%$ in trade. Two periods can be clearly distinguished between 1990 and 1996. During the first period up to 1993, all available data indicate that the size of the unofficial economy increased in relation to GDP. The second period began in 1994 and it is not possible to make a final judgement because despite the fact that a majority of indicators suggest a fall, some particularly important indicators point to an increase in the size of the unofficial economy. The calculated data for that period do not clearly show increased efficacy of tax collection by the Tax Administration, so it is highly questionable whether the present changes can be explained by greater success in tax collecting.

The calculated size of the unofficial economy in relation to GDP (25\%) is large and will probably remain so in the foreseeable future because the inherited tradition, the transition with intensified sectoral and institutional restructuring, the large state influence in the economy, especially in privatisation along with the tax pressure, the recovery of growth and new enterprise, only support the unofficial economy.

The existing quantity and persistence of the factors which influence the unofficial economy point to the fact that to be successful economic policy must take into consideration all the activities within the unofficial economy. Further research of the unofficial economy would lead not only to a better understanding of the unofficial economy but also to better efficacy of economic policy.

Economic policy aimed at suppressing the unofficial economy must: 1) reduce taxes and customs duties (to the extent permitted by the state budget); 2) selectively reduce regulation; 3) reduce the role of the public sector and the presence of the state in the economy while liberalising the economy; 4) better estimate the size of the unofficial economy within the overall economy and in individual sectors.

The aim of reducing the unofficial economy requires that: 1) laws and regulations be made more clear, precise and harmonised; 2) the independence and resources of the courts be 
reinforced; 3) statistics be improved and made more accessible; 4) the organisation, efficacy, expertise and cooperation of state organs be improved; 5) the role of the state be reduced, the economy be liberalised, public spending be rationalised and the quality of public services be improved; 6) value added tax be introduced; 7) the pension fund system be reformed; 8) paternalistic capitalism be abandoned; 9) privatisation so far be monitored and public enterprises be privatised; 10) democratic forms of supervision be strengthened. It is more important in attempting to reduce the unofficial economy to remove the causes than to punish the consequences, and here the institutional sphere is crucial (relationship between the state and the economy).

It is essential that coordinated research continues into: 1) the political economics of the unofficial economy in order to determine the future role of the state; 2) changes in the social structure, corruption, tax evasion and public opinion concerning unofficial economy; 3) economic, social, cultural and anthropological characteristics of the communities involved in the unofficial economy; 4) privatisation ; 5) tax status of small firms; 6) transparency of laws; 7) efficacy of the courts and so on.

Special attention should be paid in future research to improvement of the statistics, which must be more comprehensive and of better quality in accordance with international standards. The precise calculation of GDP is essential (nominal, real, official annual data, individual values, by the organisational principle etc.), applying the UN system of the national accounts, input-output tables, improved monitoring of formal activities, regular surveys of personal expenditure, surveys aimed at determining the unofficial economy, long and continuous series of data, etc.

\section{REFERENCES}

Abramson, P. and R. Inglehart (1995) Value Change in Global Perspective. Ann Arbor, MI: University of Michigan. Adams, C. (1993) For good and evil, the impact of taxes on the course of civilization, London: Madison Books Alessandrini, Sergio and Dallago, Bruno (ur.) (1987) The Unofficial Economy: Consequences and Perspectives in Different Economic Systems, Aldershot, Hants. Gower Publishing Company.

Alford Robert.R. and Edgar L.Feige (1989) Information distortions in social systems: the underground economy and other observer-subject-policymaker feedbacks in: Feige (eds.)(1989) pp. 57-79.

Altman Jonathan (1983) A Reconstruction Using Anthropological Methods of the Second Economy of Soviet Georgia, Ph.D. diss., Middlesex Polytechnic Institute, Enfield, England.

Amin A.T.M. (1987) The role of informal sector in economic development: Some evidence for Dhakka and Bangladesh, International Labor Review, 126(5): 611-623.

Anušić, Zoran (1994) Ponuda novca u Republici Hrvatskoj i analiza gotovinsko-depozitnog kvocijenta, Privredna kretanja i ekonomska politika, no. 31

Arora, V. B. and Kochhar, K. (1995) Discrepancies in Bilateral Trade Statistics: The Case of China, IMF paper on policy and assessment, no. PPAA/95/10.

Arts, W., Hermkens, P. and P. Van Wijck (1995) Anomie, Distributive Injustice and Dissatisfaction with Materijal Well-Being in Eastern Europe. International Journal of Comparative Sociology 36(1-2):1-15. 
Arvay J. and Vertes A. (1995) Impact of the Hidden Economy on Growth Rates in Hungary, Statistical Journal of the United Nations ECE, no. 12: 27-39

Aryee, A. G. (1976) Effects of Formal Education and Training on the Intensity of Employment in the Informal Sector: A Case-Study of Kumasi, Ghana, ILO, Geneva.

Aslung, A. (1985) Private Enterprise in Eastern Europe: The Non-Agricultural Private Sector in Poland and G.D.R, 1945-83, New York: St. Martin's Press.

Bačić, F. and Šeparović, Z. (1992) Krivično pravo posebni dio, Narodne novine, Zagreb.

Bagnasco Arnaldo and Charles Sabel (eds.) (1995) Small and Medium-Size Enterprises, London: Pinter.

Bagnasco, Arnaldo (1990) The Informal Economy, in: Martinelli, A. and Smelser, N. /eds/ Economy and Society. London: Sage.

Banović, B. (1988) Nekinblici kriminaliteta u području samostalne djelatnosti, Priručnik za stručno osposobljavanje djelatnika unutarnjih poslova, 36 (5): 417-421

Barbić, Jakša (1996) Proglašavati zloporabom i kriminalom neke radnje a koje nije dana meritorna pravna ocjena, nije dopustivo u državi vladavine prava, Vjesnik, 11. November 1996.

Bars, J.J. le; Gamus, G, Cosset, A and Nottola, Y. (1980) Essay d'Analyse des Causes Socio-economiques du Developpement du Travail Noir dans les Metiers du Batiment, Societ, d'Etudes pour le Developement Economique et Social, Etude pour le CORDES, SEDES

Barthelemy, Philippe (1988) The Macroeconomic Estimates of The Hidden Economy: A Critical Analysis, Review of Income and Wealth, 34(2) June 1988, pp. 183-208

Barthelemy, Philippe (1989) The underground economy in France, in: Feige, Edgar L.(eds.) (1989) pp. 281-296.

Bawly, D. (1982) The subterranean economy, New York, Mac-Graw Hill

Bayar, A. (1989) Migrant Women at Atypical Work, Conference: Employment in Europe in the 1990s: The Chances for a New Deal, Torino.

Bejaković, Predrag (1994) Siva ekonomija u svijetu i osnovica za njeno analiziranje u Hrvatskoj, Financijska praksa, Vol. 18, No. 2. pp.79-109

Bejaković, Predrag (1995) Metode mjerenja i fenomen sive ekonomije u Hrvatskoj, Financijska praksa, Vol. 19. No. 4, pp. 317-347

Bejaković, Predrag (1997), Macroeconomic measurement of the unofficial economy, Financijska praksa, Vol. 21. No. 1-2, pp. 71-90

Bejaković, Predrag (1997), Estimating the volume of the unofficial economy in selected economies, Financijska praksa, Vol. 21. No. 1-2, pp. 91-124

Beneria Lourdes (1989) Subcontracting and Employment Dynamics in Mexico City, in: Portes, Alejandro, Manuel Castells and Lauren A.Benton (eds.)(1989) pp.173-188

Besley Timothy (1995) Savings, Credit and Insurance, in: Behrman J. and T.N. Srinivasan (eds. )(1995) Handbook of Development Economics, Vol. III, Elsevier.

Bićanić, I. (1987) The Inequality Impact of the Unofficial Economy in Yugoslavia, in: Alessandrini, S. and Dallago, B. (eds.)(1987) pp.323-336

Bićanić, I. (1990) Unofficial Economic Activities in Yugoslavia, in: Loš, Maria (ed) The Second Economy in Marxist States. London: MacMillan.

Bićanić, Ivo (1993) Privatization in Croatia, East European Politics and Societies, Vol.7, No. 3

Blades, W. D. (1982) The Hidden Economy and the National Accounts, OECD Economic Outlook, Occasional Studies, No. 2 (28-45).

Bordignon, M. (1993) Taxing Lessons from Italy, International Economic Insights, Vol.4, No.6, pp.10-14

Borsutcky, Dieter (1992) The Transformation of the Informal Sector in Penang/Malaysia, Internationales Asienforum, Vol. 23, No. 3-4.

Bourdieu, P. (1986) The Forms of Capital, in: Richardson, J. (ed.)(1986) Handbook of Theory and Research for the Sociology of Education. New York: Greenwood.

Brezinski Horst (1985) The second economy in the Soviet Union and its implications for economic policy, in: Gaertner-Wenig (eds)(1985) pp. 362-376.

Broesterhuizen, G.A.A.M, (1989) The Unrecorded Economy and the National Income Accounts in the Netherlands: A Sensitivity Analysis, in: Feige, Edgar L.(1989) pp.159-174

Broesterhuizen, G.A.A.M. (1985) The Unobserved Economy and the National Accounts in the Netherlands: A Sensitivity Analysis, in: Gaertner, Wulf and Wenig, Alois (eds)(1985) pp. 377-391

Brus Wlodzimierz and Kazimierz Laski (1985) Repressed inflation and second economy under central planning. in: Gaertner-Wenig (eds.)(1985) pp. 377-388.

Brusco Sebastiano (1995) Local productive systems and new industrial policy in Italy, in: Bagnasco A. and C.Sabel (eds.)(1995) pp. 51-68.

Burić, I. (1996) Prema košnici, ili prema socijalnoj bombi? Privredni vjesnik, 5. February, pp. 6-7.

Burns, S. (1977) The Household Economy, Boston, Beacon Press. 
Bureaucrats in Business: The Economics and Politics of Government Ownership (1995) World Bank Policy Research Report, Washington D.C., World Bank

Business Central Europe, EIU, June 1996.

Buttler, G. (1984) Schattenwirtschaft - Grenzen der Erfassbarkeit, Deutscher Institut - Verlag.

Capecchi Vittorio (1989) The Informal Economy and the Development of Flexible Specialization in EmiliaRomagna, in: Portes Alejandro, Manuel Castells and Lauren A.Benton (eds.)(1989) pp. 189-215.

Carrol, J.S. (1992) How Taxpayers Think About Their Taxes: Frames and Values, in: Slemrod, J. (1992) pp. 43-63

Carsen, S. C. (1992) The Underground Economy: An Introduction, in: Guide Book to Statistics on the Hidden Economy, Economic Commission For Europe, Statistical Division, Geneva, United Nations, New York, pp. 28-57.

Cartaya, V. (1992) The Costs of Becoming Legal for an Informal Firm, the Case of Venezuela, in: Tokman, V. (1992) Beyond regulation, The Informal Economy in Latin America, Boulder, Colo.: Rienner.

Cassel, Dieter (1983) The Growing Shadow Economy: Implications for Stabilization Policy, paper presented to the conference on The Economics of the Shadow Economy, University of Bielefeld, October 10-14, 1983.

Cassel, Dieter and Ulrich Cichy (1987) The shadow economy and economic policy in East and West: a comparative system approach, in: Alessandrini S. and Dallago, B. (eds)(1987): 127-145.

Castells, Manuel and Alejandro Portes (1989) World Underneath: The Origins, Dynamics, and Effects of the Informal Economy, in: Portes Alejandro, Manuel Castells and Lauren A.Benton (eds.)(1989): 11-37.

Centar za istraživanje marketinga (CEMA) (1995): Putovanja - Omnibus anketa u Hrvatskoj, October 1995, Zagreb,

Centar za istraživanje marketinga (CEMA) (1995): Dodatni poslovi kućanstva u Hrvatskoj, March 1995, Zagreb.

Chavez Eliana (1992) Consequences of the Legal and Regulatory Framework in Peru's Taxi Market, in: Tokman, V. (ed)(1992): 247-275.

Chickering, A. Lawrence and Salahdine, Moahamad (1991) The Silent Revolution: The Informal Sector in Five Asian and Near Eastern Countries, San Francisco, CA., ICS Press.

Christopherson Susan (1990) Emerging Patterns of Work, in: Noyelle Thierry (ed.)(1990): 11-30.

Ciravegna, D. (1985) Aspetti Teorici del Mercato del Lavoro, G. Giappichelli - Editore, Torino.

Clark, G. (1988) Traders versus the state : anthropological approach to unifficial economies, Boulder, Weisveiw Press

Coleman, J. (1990) Foundations of Social Theory. Cambridge, MA.: Belknap.

Conseil des Impots (1979) Le Rapport au President de la Republique Relatif a l'Impot sur le Revenu, Journal Officiels de la Republique Francaise, Paris.

Constatino, C. (1992) Moving from the Exposed Economy to Determine Total Gross Domestic Product: Calculation made by ISTAT for 1982, in: Guide Book to Statistics on the Hidden Economy, Economic Commission For Europe, Statistical Division, Geneva,

Contini, B. (1979) Lo sviluppo di un'economia parallela, Edizioni di Comunita, Banca Commerciale Italiana, Milano. Contini, Bruno (1982) The Second Economy of Italy in Tanzi, Vito (1982) The Underground Economy in the United States and Abroad, Lexington Books, Massachusetts

Courtenay Adam (1996) Washed and brushed up, The Banker, October, pp 71-72.

Cowell, Frank A. (1990) Cheating the Government, Cambridge, Mass.: MIT Press.

Cowell, Frank A. (1993) What's Wrong with Going Underground? International Economic Insight, vol.4, no. 6, pp18-21

Crnković-Pozaić, S. (1997) The unofficial economy measured by labour, Financijska praksa, Vol. 21. No. 1-2, pp. 169-194

Čučković, Nevenka (1995) The Privatization Process and its Consequences for Distribution of Welfare: The Case of Croatia, MOCT-MOST, vol.5, no.3, pp 75-90

Čučković, N. (!997), The grey economy and the process of privatisation, Financijska praksa, Vol. 21. No. 1-2, pp. 259-276

Dalić, Martina, Madžarević, Saša and Nestić, Danijel (1996) Procjena mogućeg utjecaja uvođenja poreza na dodanu vrijednost na cijene u Republici Hrvatskoj, Financijska praksa,Vol. 20., No. 2, pp. 219-236

Dallago Bruno (1987) The underground economy in the West and the East: a comparative approach, in: Alessandrini S. and B.Dallago (eds.)(1987): 147-163.

De Soto Hernando (1989) The Other Path: The Invisible Revolution in the Third World, New York: Harper and Row.

Dietz, T. and P. Stern (1995) Toward a Theory of Choice: Socially Embedded Preference Construction. Journal of Socio-Economics 24(2):261-279.

DiMaggio Paul (1994) Culture and Economy, in: Smelser N.J. and R.Swedberg (eds.)(1994):27-57.

Dobbs, M. (1977) Will a Bit On the Side Keep the Poles Quiet? The Sunday Times Reading, England (September 25):8.

Dobosiewicz, Z. (1987) The Role of Unofficial Economy in North African Countries, in: Alessandrini, S. and Dallago, B. (eds) (1987) pp 165-174.

Dornbusch R. (1988) Policymaking in the Open Economy, Oxford University Press. 
Dozan, Jadranka (1996) Lažna bijeda programiranih stečajeva, Večernji list, 18. September, pp. 27.

Dozan, Jadranka (1996) Sporne dionice ohladile burzu, Večernji list, 6. November, pp. 21.

Dubravčić, Dinko and Dujšin, Uroš (1991) Makroekonomska politika i tranzicijska kriza, Zagreb, Ekonomski institut.

DZS - Državni zavod za statistiku (1994 and 1995) Priopćenje Ugostiteljstvo - ugostiteljska poduzeća brojevi: 10.02.01;10.02.02;10.02.03;10.02.04; Zagreb 1994. and 1995

DZS - Državn zavod za statistiku (1996a) Dokumentacija Turizam, No. 957; Zagreb 1996

DZS - Državni zavod za statistiku (1996b) Priopćenje Ugostiteljstvo - Ugostiteljske radnje samostalnih ugostitelja 1994. No: 10.04; Zagreb, 1996

Economic Commission For Europe (1992) Guide Book to Statistics on the Hidden Economy. Geneve: Economic Commission For Europe, Statistical Division, United Nations

Elizondo Nestor (1992) Illegality in the Urban Informal Sector of Mexico City, in:Tokman (eds.)(1992): 55-83.

Elshtain, J.B. (1995) Democracy on Trial, Basic Books, A Division of Harper Collins Publishers, INc.

Ericson, R. (1984) The Second Economy and Resource Allocation under Central Planning, Journal of Comparative Economics, 8(17):1-24.

European Trade Union Institute (1992) Collective Bargaining in Western Europe in 1991. and Prospects for 1992, Brussels.

Feige, Edgar L. (1979) How Big is the Irregular Economy, Challenge, vol. 22, Nov-Dec. pp. 5-13.

Feige Edgar L. (eds. )(1989) The underground economies: Tax evasion and information distortion, Cambridge: Cambridge University Press.

Feige, Edgar L. (1990) Defining and Estimating Underground and Informal Economies: The New Institutional Approach, World Development, vol. 18, no.7, pp. 989-1002.

Feige, Edgar L. (1993) The Myth of the Cashless Society, International Economic Insights, vol.4, no.6, pp.2-4

Feldbrugge, F. (1989) The Soviet Second Economy in a Political and Legal Perspective, in: E. Feige (eds.) (1989)

Ferman, L.A.; Berndt, L.E. and Selo, E. (1978) Analyses of the irregular economy: cash flow in the informal sector, Bureau of Employment and Training, Michigan Department of Labor and Industrial Relations, University of Michigan - Wayne State University

Fishlow, A. and J. Friedman (1994) Tax Evasion, Inflation and Stabilization, Journal of Development Economics, vol.43, no.1, pp. 105-123

Flajs, A. (1995) Obračun bruto domačega proizvoda in skrita ekonomija, IB Revija, No. 4-5, pp. 17-25

Fligstein, N. and I. Mara-Drita (1996) How to Make a Market. American Journal of Sociology 102(1):1-33.

Fligstein, N. (1996) The Economic Sociology of the Transitions from Socialism. American Journal of Sociology 101(4):1074-81.

Franičević Vojmir (1986) Radikalna politička ekonomija: Traganje za alternativom kapitalizmu SAD, Zagreb: Centar V.Bakarić/Globus

Franičević, Vojmir (1995) Small Firms and Networks: Some Policy Consideration, Zbornik radova, 13(2): 285-300, Rijeka: Ekonomski fakultet Rijeka.

Franičević, Vojmir (1997) Basic characteristics of the unofficial economy, Financijska praksa, Vol. 21. No. 1-2, pp. 45-70

Franičević, Vojmir (1997) Political economics of the grey economy - the state and regulations, Financijska praksa, Vol. 21. No. 1-2, pp. 295-314

Franz, Alfred (1984) Schatzungen der hidden economy in Österreich auf der Basis offizieller Statistiken, in: Skolka, J. (ed.) (1995) pp. 83-99.

Franz, Alfred (1985) Estimates of the Hidden Economy in Austria on the Basis of Official Statistics, Review of Income and Wealth, 31(4) December 1985, pp. 325-336

Frey, B. (1989) How Large (or Small) Should the Underground Economy Be? in Feige, Edgar L.(1989)

Frey, B. and Pommerehne, W. (1982) Measuring the Hidden Economy: Though This be Madness, There is Method in it, in: Tanzi, V. (ed.) (1982)

Frey, B; Weck, H; and Pommerehne, W. (1982): Has the Shadow Economy Grown in Germany? An Exploratory Study, Weltwirtschaftliches Archiv, vol. 118, no.3.

Fua, G. (1976) Occupazione e capacita produttiva, la realta italiana, Il Mulino, Bologna.

Gabor Istvan R.(1989) Second economy and socialism: the Hungarian experience, in: Feige Edgar L. (ed.)(1989): 339-360

Gabor, I. (1989) Second Economy and Socialism: The Hungarian Experience, in: E. Feige (ed.) (1989)

Gaertner Wulf and Alois Wenig (eds.)(1985) The Economics of the Shadow Economy, Berlin: Springer-Verlag.

Gaertner, Wulf, and Wenig, Alois (eds) (1983) The Economics of at the Shadow Economy, Proceedings of the International Conference on the Economics of the Shadow Economy held at the University of Bielefeld, Springer Verlag, Berlin.

Galasi Peter (1985) Peculiarities and limits of the second economy in socialism (The Hungarian case) in: Gaertner Wulf and Alois Wenig (eds.)(1985):353-361. 
Gapinski, J. (1996) Modelling Croatian Tax Collections, Ministry of Finance of Croatia, mimeo

Gershuny Jonathan (1978) After Industrial Society? The Emerging Self-Serving Economy, London: Macmillan.

Gershuny, J. I. (1979) The Informal Economy - its Role in Post-Industrial Society, Future, February 1979.

Gershuny, J. I. and Miles, I. D. (1985) Towards a new social economics, in Roberts, B; Finnegan, R. and Gallie. D (eds) New Approaches to Economic Life: Economic Restructuring: Unemployment and Social Division of Labour, Manchester, Manchester Univer

Gilmore, C. William (1995) Dirty money, The evolution of money laundering counter-measures, Council of Europe Press, Strasbourg.

Glas, M. (1988) Razcvet sive ekonomije v sedemdesetih letih - Pogled na razloge in dejanske razmene. in: Glas, M.; Kukar, S.; Simončić, M.; Bičanić, I. (1988)

Glas, M.; Kukar, S.; Simončić, M.; Bičanić, I. (1988): Siva ekonomija v svetu in v Jugoslaviji, Delavna enotnost, Ljubljana.

Goić, S. (1995) Cultural Values and Attitudes as a Factor of Capacity of Former Communist Countries in their Transition. in: Enterprise in Transition. Split: University of Split.

Gordon David M., Richard Edwards and Michael Reich (1982) Segmented work, divided workers: The historical transformation of labor in the United States, Cambridge: Cambridge University Press.

Graafland, J.J. (1990) Tax Policies And Interaction Between Hidden And Official Economy, Public Finance, vol.45, no. 1 , pp. $70-89$

Gracin, Zdravko (1996) Carstva nestaju nečujno, Novi list, 17. August, pp. 9

Granovetter, M. (1985) Economic Action and Social Structure: The Problem of Embeddedness. American Journal of Sociology 91(3):481-510.

Granovetter, M. (1990) The Old and the New Economic Sociology: A History and an Agenda, in: Friedland, R. and Robertson, A. (eds.) (1990) Beyond the Marketplace. New York: Aldine.

Gray June (1987) Conference on the comparative study of the informal sector, International Journal of Urban and Regional Research, 11(September): 421-423.

Greenfield Harry I. (1993) Invisible, Outlawed, and Untaxed: America's Underground Economy, Westport, CT Praeger

Grimstone, Jack (1996) Rebuilding Croatia: Year One, Business Central Europe, EIU, June 1996, pp. 18-19.

Grossman Gregory (1989) Informal Personal Incomes and Outlays of the Soviet Urban Population, in: Portes, Castells and Benton(eds.)(1989): 150-170.

Grossman, Gregory (1977) The Second Economy of the USSR. - Problem of Communism, 26(5):25-40

Grossman, Gregory (1993) The Underground Economy in Russia, International Economic Insights, vol.4, no.6, pp.14 $-18$

Grossman, Gregory and Treml, G. V. (1987) Measuring hidden personal incomes in the USSR, in: Alessandrini, S. and B. Dallago (eds)(1987) pp. 285-301

Guinsburg, V. and Pestieau, P. (1987) L'economie informelle, Editions Labor, Bruxelles.

Gupta, S.B. (1992) Black Income in India, New Delhi etc, Sage Publication

Gutmann, M. P. (1979) Statistical Illusions, Mistaken Policies, Challenge, Nov-Dec. pp. 14-17

Gutmann, P.M (1977) Subterranean Economy, Financial Analyst Journal, November

Guy, P.B. (1991) The Politics of Taxation: A Comaparative Perspective, Cambridge, London: Blackwell, pp. 192224

Halman, L. (1995) Is There a Moral Decline? A Crossnational Inquiry into Morality in Contemporary Society. International Social Science Journal 145:419-39.

Hansson Ingemar (1982) The Underground Economy in the High Tax Country: The Case of Sweden in: Tanzi, Vito (ed.)(1982)

Harding, P. and Jenkins, R. (1989) The Myth of Hidden Economy, Towards a New understatding of Informal Economic Activity, Open University Press, Milton Keynes, Philadelphia.

Harrison Bennett (1994) Lean and Mean: The Changing Landscape of Corporate Power in the Age of Flexibility, New York: Basic Books.

Hart Keith (1973) Informal Income Opportunities and Urban Employment in Ghana, Journal of Modern African Studies, 11: 61-89

Hart Keith (1987) Informal economy, in: The New Palgrave: A Dictionary of Economics, 1987, vol. II: 845-846

Haskell, M.R. and Yablonsky, L. (1974) Crime and Delinquency, Rond McNally, Chicago.

Hausman Daniel M. and Michael S. McPherson (1996) Economic analysis and moral philosophy, Cambridge: Cambridge University Press

Heertje, A.and Barthelemy, P. (1984) L'Economie Souterraine, Paris, Economica.

Henry, Stuart (1978) The Hidden Economy: The Context and Control of Borderline Crime, London: Martin Robertson.

Henry, J.S. (1983) Non-Compliance with US Tax Law - Evidence of Size, Growth and Composition in: Sawicki, P. (eds.) (1983) Income Tax Compliance Research, American Bar Association, Washington DC. 
Heršak, G.B. (1995) Borba protiv organiziranog kriminala i pranja novca, Policija i sigurnost, 4 (3): 168-178.

Hillman, Arye (1996) Informal Sector and Bariers to Growth, referat prezentiran na konferenciji Hidden Barriers to Economic Growth, Sofia, 14. April 1996. with USAID and Institute for Market Economics, Sofia

Horvat, K. (1995) Prijevare u gospodarstvu, Policija i sigurnost, 4 (4): 304-310.

Horvatić, Ž. (1994) Elementarna kriminologija, Školska knjiga, Zagreb.

House William J. (1984) Nairobi's Informal Sector: Dynamic Entrepreneurs or Surplus .

Labor?, Economic Development and Cultural Change, vol.32, no.2, pp 277-302

Houston Joel F. (1987) Estimating the Size and Implications of the Underground Economy, Frederal Reserve Bank of Philadelphia Working Paper No. 87-91

Hrvatski fond za privatizaciju (1996) Izvješće o pretvorbi i privatizaciji, 10. October.

Hrvatsko gospodarstvo (1996) No. 87

ILO (1972) Employment, Incomes and Equality: A Strategy for Increasing Productive Employment in Kenya, Geneva, ILO

ILO -Jobs and Skills Programme for Africa (1985): Informal Sector in Africa, Adis Abeba.

IMF (1993-1996) Direction of Trade Statistics, Quarterely

Ingham, G. (1996) Some Recent Changes in the Relationship Between Economics and Sociology. Cambridge Journal of Economics 20:243-75

Inglehart, R. (1995a) Changing Values, Economic Development and Political Change. International Social Science Journal 145:379-403

Inglehart, R. (1995b) Modernization and Postmodernization: Cultural, Economic, and Political Change in 43 societies

Inman Robert P. (ed.)(1985) Managing the Service Industry: Prospects and Problems, Cambridge: Cambridge University Press.

Institut za turizam (1994) Stavovi i potrošnja turista u Hrvatskoj TOMAS 94; Zagreb

Inter-Secretariat Working Group on National Accounts (1993) System of National Accounts 1993, Eurostat, IMF, OECD, UN and World Bank, Brussels/Luxembourg, New York, Paris, Washington, D.C.

Isachsen, A.J.; Samuelson, S. O. and Strom, S. (1985): The Behaviour of Tax Evaders, in: Gaertner, W. and Wenig, A. (eds.)(1985) pp. 227-244

Ivandić, N. and Radnić, A. (1995) Učinci poreza na dodanu vrijednost na poslovanje hotelijerstva; Turizam, vol. 43, no. 5-6, pp. 91-101

Ivandić, N. and Radnić A. (1997), The grey economy in tourism and catering, Financijska praksa, Vol. 21. No. 1-2, pp. 231-240

Jambrović, Dražen (1996) Perače treba dočekati - spreman, Privredni vjesnik, pp. 5.

Jankov, Lj. (1997) The monetary form of the unofficial economy, Financijska praksa, Vol. 21. No. 1-2, pp. 157-168

Jaspan, N. and Black, H. (1960) The theif in the white collar, Lippoincott, New York.

Jelenski, M. (1989) Pojavni oblici načina izvršenja kriminala na benzinskim stanicama, Priručnik za stručno obrazovanje radnika unutarnjih poslova, 37 (2): 453-460.

Jelenski, M. (1991) Kriminalističko poimanje tamnog polja kriminaliteta, Zbornik radova nastavnika i suradnika Više škole unutarnjih poslova, Fakultet kriminalističkih znanosti Zagreb, Zagreb

Jessen, J., Siebel, W., Siebel-Rebell, C., Walther, U.-J., Wezrather, I. (1987): The informal works of industrial workers. Present situation, trends prognosis and policy implication, in: Alessandrini S. and Dallago B. (eds.) (1987) Johnson, T. Brian and Sheehy, P. Thomas (1996): 1996 Index of Economic Freedom, Washington, The Herritage Foundation

Joshi, H., Lubell, H. and Mouly, J. (1976) The Urban Informal Sector, Abidjan: Urban Development and Employment in the Ivory Coast, ILO, Geneva

Jung, Y.H., Snow, A. and G.A.Trandel (1994) Tax Evasion and Size of the Underground Economy, Journal of Public Economics, vol.54, no.3, pp.391-402

Jurčević, Ž. (1996) Ostvarivanje Socijalnog programa u Republici Hrvatskoj. Revija za socijalnu politiku 3(1):31-44

Kant, C. (1996) Foreign Direct Investment and Capital Flight, Princeton Studies in International Finance, no. 80.

Kesner-Škreb, Marina (1996) Pojmovnik javnih financija - Sivo gospodarstvo, Financijska praksa, vol. 20, br. 3, pp. 373-375

Kesner-Škreb, Marina (1997) Development and the grey economy, Financijska praksa, Vol. 21. No. 1-2, pp. 315-328

Kinnicutt, T. M. (1989) Italy, finita la commedia, International Management, 44(10):60-66.

Knight, J. (1994) Institutions and Social Conflict. Cambridge: Cambridge University Press.

Korbonski, A. (1981) The Second Economy in Poland, Journal of International Affairs 35(1)(Spring-Summer):1-15.

Kornai, Janos (1980) Economics of Shortage, Amsterdam: North Holland.

Kos, J. (1991): Privredni prijestupi, Narodne novine, Zagreb

Krapac, D. (1987): Međunarodna krivičnopravna pomoć, Informator, Zagreb.

Kukar, Stanka (1995) Siva ekonomija v Sloveniji: Razlogi za njen razvoj in ocene njenega obsega, IB revija, vol. 29, no.1-2-3, pp. 16-25 
Landaw, Z. (1987) Selected Problems of the Unofficial Economy in Poland, in: Alessandrini, S. and B. Dallago (eds.)(1987) pp.175-180

Langfeld, Enno (1983) Die Schattenwirtschaft in der Bundesrepublik Deutschland, J.C.B. Mohr, Tubingen

Lehner, G. (1984) Schattenwirtschaft und der ffentliche Sektor, in: Skolka, J. (ed.)(1984) pp. 121-130

Lewis, A., Webley, P. and A. Furnham (1994) The New Economic Mind: The Social Psychology of Economic Behaviour. New York: Harvester Wheatsheaf.

Light, Ivan and Stavros Karageorgis (1994) The Ethnic Economy, in: Smelser N.J. and R.Swedberg (eds.)(1994) pp. 647-671

Livingstone, Ian (1991) A Reasssessment of Kenya's Rural and Urban Informal Sector, World Development, 19(6)

Loš, M. (ed.)(1990) The Second Economy in Marxist States, Macmillan, Hong Kong.

Loš Maria (1990) Dynamic Relationships of the First and Second Economies in Old And New Marxist States, in: Loš, Maria (ed.)(1990) pp.193-229

Loayza, Norman V. (1994) The Informal Sector and Economic Growth, doktorska disertacija, Harvard University, Cambridge, Massachusetts

Lomnitz, Larissa A. (1988) Informal Exchange Networks in Formal Systems: A Theoretical Model, American Anthropologist, 90: 42-55.

Loveman, Gary and Werner Sengenberger (1990) Introduction - Economic and social reorganisation in the small and medium-sized enterprise sector, in: Sengenberger Werner, Gary W. Loveman and Michael J. Piore (eds.)(1990) pp. $1-61$.

Lubbell, H. (1991) The Informal Sector in the 1980s and 1990s, Development Centre of the Organisation for Economic Co-operation and Development, Paris

Lyman, S. (1986) Chinatown and Little Tokyo. Millwood, NY: Associated Faculty Press.

Madžarević, Sanja (1997) Tax evasion, Financijska praksa, Vol. 21. No. 1-2, pp. 241-258

Madžarević, Sanja and Mikulić Davor (1997) Measuring the unofficial economy with a system of national accounts, Financijska praksa, Vol. 21. No. 1-2, pp. 141-156

Marin, N. (1996) Izravna strana ulaganja u Republici Hrvatskoj, Statističko istraživanje, radna verzija.

Marinković, K. and A. Štulhofer (1993) Mjesto pod suncem: modeli aktera i refrakcija racionalnosti. Revija za sociologiju 24(1-2):17-31.

Mauro, Paolo (1995) Corruption and Growth, The Quarterly Journal of Economics, vol. 110, no. 3, pp. 683-712

Maver, D. (1991) Pojedini aspekti i problemi dokazivanja otkrivenih krivičnih djela na području transformacije društvenog vlasništva, Priručnik za stručno obrazovanje radnika unutarnjih poslova, 39 (6): 464-569.

McBarnet, D. (1991) Whiter Than White Collar Crime: Tax, Fraud Insurance And The Management Of Stigma, The British Journal of Sociology, vol.42, no.3, pp.323-344

McCarthy, P. (1993) Italy: The Absent State, International Economic Insights, vol.4, no.6, pp.6-10

Mead, C. Donald and Morrisson, Christian (1996) The Informal Sector Elephant, World Development, vol. 24, no. 10, pp. 1611-1619

Meier, Gerald G. (1995) Leading Issues in Economic Development, 6th ed., New York: Oxford University Press.

Merrick, W. T. (1976) Employmentant Earning in the Informal Sector in Brazil: The Case of Belo Horizonte, The Journal of Developing Areas, April

Miklos, Ivan (1996) Corruption Risks in the Privatization Process, Academic Electronic Press, Bratislava, Slovak Academy of Sciences

Mikulić Davor and Madžarević Saša (1997) Estimating the unofficial economy in agriculture, industry and trade, Financijska praksa, Vol. 21. No. 1-2, pp. 217-230

Miljević, B. (1989) Organizacija i strategija suzbijanja i otkrivanja privrednog kriminaliteta, Priručnik za stručno obrazovanje radnika unutarnjih poslova, 37 (3): 269-274.

Mogelsen, G. V. (1992) Black Markets and Welfare in Scandinavia: Some Methodological and Empirical Issues, in: Guide Book to Statistics on the Hidden Economy, Economic Commission For Europe, Statistical Division, Geneve, United Nations

Mooslechner, P. (1983) Der monetare Ansatz zur parallelen Wirtschaft, Wirtschaftpolitische Blatter, no. 4., pp. 121132.

Morris, L.D. (1987) Local social polarization: a case study of Hartlepool, International Journal of urban and regional research, vol.11, pp. 331-350.

Mueller Dennis C. (1989) Public Choice II, Cambridge: Cambridge University Press.

Načela fiskalne politike Republike Hrvatske u razdoblju 1997-1999: Strategija i projekcija, (1996) dokument Ministarstva financija

Neubauer, H. (1984) Schwarzarbeit und Eigenleistung in der Österreichischen Bauwirtschafts. in: Skolka, J. (ed) (1984) pp. 131-160

Nihan, G., Demol, E. and Jondoh, C. (1979) The Modern Informal Sector in Lome, International Labour Review, 118(5):546-562 
North Douglass C. (1990) Institutions, Institutional Change and Economic Performance, Cambridge: Cambridge University Press

North, Douglas (1991) Institutions. Journal of Economic Perspectives 5(1):97-112.

Novoselec, P. (1996) Kriminalističko značenje i pravno uređenje pranja novca, Tvrtka, 1 (9): 41-43

Noyelle Thierry (ed.)(1990) Skills, Wages and Productivity in the Service Sector, Boulder: Westview Press

Nusbaumer Jacques (1987) The Services Economy: Lever to Growth, Boston: Kluwe Academic Publishers

O'Hearn, D. (1980) The Consumer Second Economy: Soviet Studies, 32(2):218-243.

O'Higgins Michael (1985) The relationship between the formal and hidden economies: An explanatory analysis for four countries, in: Gaertner and Wenig (eds.)(1985) pp. 127-143.

Obradović, J. (ed.) (1982) Psihologija i sociologija organizacije. Zagreb: Školska knjiga.

Offe, Claus (1985) Disorganized Capitalism: Contemporary Transformations of Work and Politics, Cambridge: Polity Press

Olson, Mancur (1982) The Rise and Decline of Nations: Economic Growth, Stagflation and Social Rigidities, New Haven, Yale University Press.

Pahl, R.E. (1980) Employment, work and domestic division of labour, International Journal of Urban and Regional Research, vol.4, pp.1-20

Papeš, D. (1989) Analiza strukture otkrivenog kriminaliteta i mogućnosti njegove korekcije sa tamnom brojkom, Priručnik za stručno obrazovanje radnika unutarnjih poslova, 37 (4): 291-297.

Papeš, D. (1990) Osnovni modeli napada na imovinu; Priručnik za stručno obrazovanje radnika unutarnjih poslova, 38 (1): 63-83.

Pardo, I. (1995) Morals of Legitimacy in Naples: Streetwise about Legality, Semi-legality and Crime. European Journal of Sociology 36(1):44-71.

Patrizi, V. (1992) Measures of Concealed Employment: Pitfalls and Insights, in: Guide Book to Statistics on the Hidden EconomyEconomic Commission For Europe, Statistical Division, Geneve, (United Nations, New York) 118138.

Pavišić, B. (1991) Pojave suvremenog zločina-gospodarski zločin; Priručnik za stručno obrazovanje radnika unutarnjih poslova, 39 (5): 339-341

Peattieau, L. (1987) An idea in good currency and how it grew : the informal sector, World Development, vol. 15, no.7, pp. 851-860

Pestieau, P. (1985) Belgium's Irregular Economy, in: Gaertner, W. and Wenig, A. (eds.) (1985) pp. 144-159

Pommerehne, W.W. and H. Weck-Hannemann (1995) Tax rates, tax administration and income tax evasion in Switzerland, Kluwer Academic Publishers

Porter, R. (1993) Foreign Holding of US Currency, International Economic Insight, vol.4., no. 6, pp.5

Portes, Alejandro (1994) The Informal Economy and Its Paradoxes, in: Smelser, Neil J. and Richard Swedberg (eds.)(1994) pp. 426-449

Portes, Alejandro and Sassen-Koob, Saskia (1987) Making it underground: Comparative material on the informal sector in western market economies, American Journal of Sociology, 93(1): 30-61.

Portes, Alejandro, Castells, Manuel and Benton, Lauren A.(eds.)(1989) The Informal Economy: Studies in Advanced and Less Developed Countries, Baltimore: The John Hopkins University Press

Portes Alejandro, Blitzer, Silva and Curtis, John (1986) The urban informal sector in Uruguay: Its international structure, characteristics, and effects, World Development, 14(6): 727-741.

Portes, Alejandro, Castells, M. and L. Benton (1989) Conclusion: The Policy Implications of Informality, in: Portes, Alejandro, M. Castells and Benton, L. (eds.)(1989)

Portes, Alejandro, Castells, M. and L. Benton (1989) The Policy Implications of Informality, in: Portes, Alejandro, M. Castells and Benton, L. (eds.) (1989)

Powell Walter W.(1990a) Neither Market nor Hierarchy: Network Forms of Organization, Research in Organizational Behavior, 12:295-336.

Powell Walter W. (1990b) The Transformation of Organizational Forms: How Useful Is Organization Theory in Accounting for Social Change?, in: Friedland, Roger and A.F.Robertson (eds)(1990) Beyond the Marketplace: Rethinking Economy and Society, New York

Pozo, S. (1996) Exploring the Undergorund Economy, W.E. Upjohn Institute for Employment Research, Kalamazoo, Michigan

Privatizacija (1996a) vol.2., no. 15. March

Privatizacija (1996b) vol.2., no. 19/20. August

Puljiz, V. (1994) Socijalna politika postsocijalističkih zemalja. Revija za socijalnu politiku 1(1):83-90.

Putnam, R. (1993) Making Democracy Work. Princeton: Princeton University Press.

Pyle, D.J. (1989) Tax Evasion and the Black Economy, New York, St. Martins Press

Rajan Amin (1987) Services - The Second Industrial Revolution?, London: Butterwoths.

Ralašić, Marina (1996) Pet ekonomskih zločina, Banka, No. 11, pp. 27-38.

Ranis Gustav (1987) Labour surplus economies, in: The New Palgrave Dictionary, London: Macmillan 191-198 
Rauch, J.E. (1991) Modelling the Informal Sector Formally, Journal of Development Economics, vol. 35, no.1, pp. 33-47

Reljac, Branka (1997) The unofficial economy in trade, Financijska praksa, Vol. 21. No. 1-2, pp. 195-216

Roberts, R. B. (1989) Employment Structure, Life Cycle: and Life Chaces: Formal and Informal Sectors, in: Portes, Alejandro, Castels. M and Benton, L.A.(1989)

Rohatinski, Željko and Santini, Guste (1994) Pretvorba: odakle dolazimo ... kamo idemo?, RIFIN, Zagreb

Roller, D. (1992) Kako onemogućiti fiskalni kriminalitet; Financijska praksa 16 (7-8): 455-464

Rona-Tas, A. (1994) The First Shall be the Last? Enterpreneurship and Communist Cadres in the Transition from

Skorupan Vesna (1997) Legal aspects of the grey economy - general traits of behaviou as a phenomenom, Financijska praksa, Vol. 21. No. 1-2, pp. 329-346

Socialism. American Journal of Sociology 100(1):40-69.

Rose, R. (1983) Getting by in the Three Economies: The Resources of the Official, Unofficial and Domestic Economies, University of Strathclyde

Rosenbluth, Guillermo (1994) The informal sector and poverty in Latin America, CEPAL Review, 52: 155-175

Ruggeri, Fedele (1987) Unofficial Economy and the Meaning of Labour: Toward a Theoretical Hypothesis, in: Alessandrini, S. (1987)

Samorodov, A. (1991) Labour market problems and developments in the Republics. in: Standing, G. (1991) In search of flexibility, The new Soviet labour market, International Labour Office, Geneva

Samuels, W. (1995) The Present State of Institutional Economics. Cambridge Journal of Economics 19:569-590

Sassen-Koob, Saskia (1989) New York City's Informal Economy, in: Portes Alejansdro, M.Castells and L.A.Benton (eds.)(1989) pp. 60-77

Schlicht Ekkehart (1985) The shadow economy and morals: a note, in: Gaertner Wulf and Alois Wenig (eds.)(1985) pp. 265-271

Schrage, H. (1984) Schattenwirtschaft - Abgrenzung, Definition, Methoden der quantitativen Erfassung, in: Schaefer, W. Hg. (1984) Schattenoekonomie, Theoretische Grundlagen und Wirtschaftspolitische Konsequenzen, Goettingen, Vandenhoeck und Ruprecht.

Schulz, James (1992) Economic Support in the Old Age: The Role of Social Insurance in Developing Countries, 24. Redovna Skupština International Social Security Association.

Schulze, G.G. (1994) Misinvoicing Imports: The Interdependence of Tax and Tariff Evasion, Public Finance Quarterly, vol.22, no.3, pp.335-365

Sekulić, Duško (1990) 'Samoupravni' i 'etatistički' model razvoja, in: R. Kalanj, Rade (ed.) Modernost i modernizacija. Zagreb: Hrvatsko sociološko društvo.

Sengenberger Werner, Gary W. Loveman and Michael J. Piore (eds.)(1990) The re-emergence of small enterprises: Industrial restructuring in industrialised countries, Geneva: International Institute for Labour Studies.

Sethuraman, S.V. (1981) The Urban Informal Sector in Developing Countries: Employment, Poverty and Environment, ILO, Geneve.

Shelley, L. (1990) The Second Economy in the Soviet Union, in: Loš, Maria (ed.)(1990) The Second Economy in Marxist States. London: MacMillan.

Shelley, L.I (1983) Law and the Soviet Second Economy, Research in Law, Deviance and Social Control, 5(34) 3-24. Siesto, V. (1992) Concept and Methods Involved in the last Revision of Italy's GDP, in: Guide Book to Statistics on the Hidden EconomyEconomic Commission For Europe, Statistical Division, Geneve, (United Nations, New York) pp. 152-176.

Simon, C.P. and A.D. Witte (1982) Beating the System: The Underground Economy, Boston, Auburn House Publishing Co.

Singer, M. (1994) Kriminologija, Nakladni zavod Globus, Fakultet za defektologiju Zagreb, Zagreb.

Skolka, Jiri (1987) A few facts about the hidden economy, in: Alessandrini S. and B.Dallago (eds.)(1987): 35-59.

Skolka, Jiri (ed.)(1984) Die andere Wirtschaft: Schwarzarbeit and Do-it-yourself in Österreich, Signum, Viena.

Skolka, Jiri (1987) A New Fact about the Hidden Economy in: Alessandrini, S and Dallago B. (1987)

Skolka, Jiri (ed.) (1995) Die andere Wirtschaft: Schwartz und Do-it-yourself in Osterreich, Wien, Signum Verlag.

Slemrod, J. (1990) Optimal Taxation and Optimal Tax System, Journal of Economic Perspectives, vol.4, no.1, pp. $157-178$

Smith, D. J. (1982) The Measuring of Selected Income Flows in Informal Markets, Report for The Internal Revenue Services, no. TIR81-28, April

Smith, J. (1981) Measuring the Informal Economy, Science Annals, vol. 493, September 1981, pp. 83-99

Smith, M.C. (1992) Red Square, London, Harper Collins Publishers.

Smith, S. (1989) European Perspectives of the Shadow Economy, European Economic Review, vol. 33, no.2/3, pp. 589-596

Smith, S. and Wied-Nebbeling, S. (1986) The Shadow Economy in Britain and Germany, Anglo-German Foundation for the Study of Industrial Society, London. 
Standing Guy (1989) The 'British Experiment': Structural Adjustment or Accelerated Decline?, in: Portes, Castells and Benton (eds.)(1989) pp. 279-297.

Standing, G.(ed.) (1991) Introduction: In search of flexibility, The new Soviet labour market, International Labour Office, Geneva.

Starobin, P. (1994) The Economy You Can't See, National Journal, June 18, pp.1406-1410

Stepick Alex (1989) Miami's Two Informal Sectors, in: Portes Alejandrom, Castells, M. i L.A.Benton (eds.)(1989) pp. 111-131

Sullivan, S. (1986) Favourable Conditions for European Black Workers, Newsweek, (30. June 1986) Newsweek, Inc., New York

Super, D. and B. Šverko (eds.)(1995) Life Roles, Values, and Careers. San Francisco: Josey-Bass.

Swedberg, R. (1991) Major Traditions of Economic Sociology. Annual Review of Sociology 17:251-76.

Sweezy, M. P. (1980) Post-Revolutionary Society, Monthly Review, 118(1):45-61.

Szalchman, R. and Uthoff, A. (1992) Sistema de Pensiones en America Latina: Diagnostico y Alternativas de Reform, Comision Economica para America Latina, Santiago, Chile

Szita, E. (1987) New types of entrepreneurial and organizational forms in the Hungarian economy, and: Alessandrini, S. and Dallago, B. (eds.)(1987) pp. 181-193

Sztompka, P. (1992) Dilemmas of the Great Transition. Sisyphus: Social Studies 8(2):9-27

Šeparović, Z. (1989) Kriminoligija i socijalna patologija, Narodne novine Zagreb.

Šonje, Velimir and A. Štulhofer (1995) Ne tako opasne veze sociologije i ekonomike: skica socioekonomskog modela institucionalne promjene. Revija za sociologiju 26(3-4):189-202.

Štulhofer, Aleksandar (1994) Kuda nakon ekonomskog imperijalizma? Politička misao 26(3-4):117-36.

Štulhofer, Aleksandar (1996) O racionalnosti, normama i institucijama: evolucija sociokulturnog kapitala kao model institucionalne promjene. Društvena istraživanja 4(6):953-81.

Štulhofer, Aleksandar and K. Kufrin (1996) Od obilja do altruizma i druge ekološke priče: postmaterijalistički sindrom i ekološke vrijednosti u Hrvatskoj. Socijalna ekologija 5(2):171-84.

Štulhofer, Aleksandar (1997) Social and cultural aspects of the unofficail economy - between opportunism and distrust, Financijska praksa, Vol. 21. No. 1-2, pp. 125-140

Štulhofer, Aleksandar (1997) The political economy and grey economy - socio-cultural dimension and tax evasion, Financijska praksa, Vol. 21. No. 1-2, pp. 277-294

Tanfield, J. (1984) The Black Economy, Background Paper No. 151, House of Commons, Library Research Division, pp. $1-10$

Tanzi, Vito (1980) Underground Economy on Illicit Pursuits is Growing Concern of Economic Policymakers, IMF Survey, Washington, Feb. 4, pp. 34-37

Tanzi, Vito (ed.)(1982) The Underground Economy in the United States and Abroad Lexington Books, D.C. Heath and Co. Lexington, Massachusetts

Tanzi, Vito (1983) The underground economy: The causes and consequences of this worldwide phenomenon, Finance\&Development, 20(4): 10-13.

Tanzi, Vito (1983) The Underrground Economy in the United States: Annual Estimates, 1930-1980, IMF Staff Papers, vol. 30

Tanzi, Vito (1996) Ekonomske promjene i politike koje potiču dugoročan rast - Pogovor, Financijska praksa, vol. 20., br. 3., pp. $363-372$

Tanzi, Vito and P. Shome (1993) A Primer on Tax Evasion, IMF Staff Papers, Vol.40, No.4, pp. 807-828

Tanzi, Vito and Schuknecht, Ludger (1996) Reforming Government in Industrial Countries Finance \& Development, no.3.

Thomas J.J. (1992) Informal Economic Activity, Ann Arbor: The University of Michigan Press.

Tokman Victor E. (ed.)(1992) Beyond Regulation: The Informal Economy in Latin America, Boulder\&London: Lynne Rienner Publishers

Tokman Victor E. and Emilio Klein (eds.)(1996) Regulation and the Informal Economy: Microenterprises in Chile, Ecuador, and Jamaica, Boulder\&London: Lynne Rienner Publishers.

Trotman, D. I. and Dickenson (1996) Economics of the public sector, London: Macmillan

US. Department of the Treasury, The Internal Revenue Services, (1983) Income Tax Compliance Research: Estimates for 1979-1981, Department of the Treasury, Washington DC.

Varese, F. (1994) Is Sicily the Future of Russia? Private Protection and the Rise of the Russian Mafia. European Journal of Sociology 35:224-58.

Vojnić, D. (1996) Zemlje u tranziciji, Ekonomski pregled, 47(5-6):263-281.

Wadhawan, S.C. (1992) Evasion, Partial Detection and Optimal Tax Policy, Public Finance, vol.47, Suppl. pp.372383

Waldinger Roger (1990) Immigrant enterprise in the United States, in: Zukin Sharon and Paul DiMaggio (eds.)(1990) Structures of Capital: The social organization of the economy, Cambridge:Cambridge University Press, pp. 395-424 
Webley, P. etc.(1991) Tax Evasion: An Experimental Approach, Cambridge etc., Cambridge University Press Weck-Hannemann, H. and Frey, B.S. (1985) Measuring the Shadow Economy: The Case of Switzerland, in: Gaertner, W.; Wenig. A. (eds.) (1985) pp. 76-104.

Weeks, John (1975) Policies for expanding employment in the informal sector of developing economies, International Labor Review, 111(1): 1-14.

White, T. P. (1991) Cuba at a Crossroads, National Geographic, 180(2):90-121.

Wiles, P. (1987) The Second Economy, Its Definitional Problems, in: Alessandrini, S. and B. Dallago (eds.)(1987) pp. 21-33

Willard, J-C. (1992) The Underground Economy in National Account, in: Guide Book to Statistics on the Hidden Economy, Economic Commission For Europe, Statistical Division, Geneve, (United Nations, New York) pp. 79-103 Williamson, O. (1985) The Economic Institutions of Capitalism. New York: Free Press.

Witte, D. A. (1987) The nature and extent of unrecorded activity: a survey concentrating on recent US research, in: Alessandrini S. and Dallago B. (eds.)(1987) pp. 61-82

World Bank (1983) World Development Report, World Bank and Oxford University Press

World Bank (1992) World Development Report, World Bank and Oxford University Press

WTO - World Tourism Organization (1995a) Concepts, Definitions and Classifications for Tourism Statistics - A Techical Manual Seminar Tourism Statistics in Central and Eastern European Countries; Madrid, January

WTO - World Tourism Organization (1995b) Collection of Tourism Expenditure Statistics; Seminar Tourism Statistics in Central and Eastern European Countries;

Zdunić, S., Baletić, Z. and J. Bendeković (1991) Privatizacija u politici gospodarskog razvoja, Zagreb, Ekonomski institut

Županov, Josip (1977) Sociologija i samoupravljanje. Zagreb: Školska knjiga.

Županov, Josip (1995) Poslije potopa. Zagreb: Globus.

***(1996) Tax Heavens, Time Magazine, Global Investing, 24th October, Special Advertising Section.

***(1996) Zgrćite i vi superdobit pomoću stavke greške i propusti, Privredni Vjesnik, pp 17.

***(1996) Human Development Under Transition. New York: UN Development Programme

***(1996) Carstva nestaju nečujno, Novi List, 17. August 1996, pp. 9

***(1996) Hungary: Privatization Scandal, Oxford Analytica East Europe Daily Brief 11. October 1996 